\title{
On a Palaeozoic Fern, the Zygopteris Grayi of Williamson.
}

\author{
BY \\ D. H. SCOTT, F.R.S., P.L.S. \\ With Plates I-V and one Figure in the Text.

\section{INTRODUCTION.}

$\mathrm{T}$

HE species Zygopteris Grayi was founded by Williamson in 1888 (Williamson, '89) on some specimens in a nodule from Oldham, which, though imperfectly preserved, enabled him to recognize the chief points in the morphology of the plant. Williamson had previously recorded a stem of the same type under the name of Anachoropteris Decaisnii, Renault (Williamson, '74, p. 699).

A much better specimen than any of those described by Williamson was found later by Mr. J. Lomax, who was also the discoverer of the typespecimens. Five sections of this stem are in Williamson's collection, but his intention of figuring it was never carried out. ${ }^{1}$ Figures have since been published by myself (Scott, '00, Figs. 97, $98^{2}$ ), Dr. P. Bertrand ('09, P1. XI, Fig. 78), and Dr. Kidston ('10, Figs. I-4), but the specimen has never been fully illustrated.

In I9I0 I received from Mr. Lomax a series of sections of a new specimen from a fresh locality-Shore, Littleborough, so well known for other interesting fossils with their structure preserved. The present paper is based primarily on the new specimen, with comparative references to the others and especially to the best Williamson specimen mentioned above. The question whether all known specimens can really be referred to the one species, $Z$. Grayi, will be discussed in the latter part of the paper.

It will be well to preface the detailed observations with a short summary of what is already known of the structure of the Zygopteris Grayi type.

1 I know of eight sections (all transverse) of this specimen, namely I8I8 A and I9I9A to I9I9 D in the Williamson Collection (see p. 66), 308 in that of Dr. Kidston, R. 443 in the Manchester Museum Collection, and 184 in my own. The proper order of these sections will be given below (p. $5^{2}$ ). The sections of the type-specimens in the Williamson Collection are : I $817-1843$ (excl. I8I 8 A) and I9I9.

2 Figs. I 15,116 in the second edition, Scott, ' 08.

[Annals of Botany, Vol. XXVI. No. CI. January, zgra. 
The stem has a very characteristic transverse section, owing to the form of the stele, which represents a five-rayed star with the rays or arms of unequal length (Pl. II, Phots. II-I3); each arm of the stele corresponds to the insertion of a leaf-trace ; the phyllotaxis is $\frac{2}{5}$, and the longest arm is that which is next going to give off a trace, while the shortest arm is that which has last done so. The most prominent arms are truncate, the broad end assuming a bicornute form. The main mass of the wood consists of a wide zone of large scalariform tracheides ; this zone, the peripheral xylem, encloses a central mass of tissue, which, like the stele as a whole, is stellate, having narrow protrusions which pass out into the projecting arms. $U p$ to I 900 this central tissue was described as a pith, with the tacit assumption that it constituted a mass of parenchyma. This, however, has been shown not to be the case (Scott, '00, p. 28I, Fig. $98^{1}$ ). The central tissue contains numerous tracheides, much smaller than those of the main zone of wood. They are accompanied by parenchyma and are ranged in an irregular ring round the centre of the stele: from this central ring radial tracts of small tracheides extend outwards, up the middle of each arm of the stele; it is among the internal tracheides of the arms that the protoxylem of the stem is situated. Groups of small tracheides also occur externally at the extremities of the more prominent xylem-arms; where the arm is truncate or bicornute they form two groups, one at each angle. The nature of these external groups of small xylem-elements will be discussed below; they are connected at certain points with the internal tracheides of the xylem-arms.

The phloem surrounds and follows the outline of the xylem. It contains a single or double band of large elements, no doubt the sieve-tubes, which, however, are for the most part limited to the bays of the stele, only extending round the xylem-arms where the latter are at their shortest, having just given off a leaf-trace.

Immediately surrounding the stele is a comparatively narrow zone of inner cortex consisting of thin-walled parenchyma; beyond this comes the broad and dense outer cortex, succeeded on the outside by a few layers of delicate hypoderma and the epidermis bearing multicellular hairs.

The stem bears appendages of four kinds: (I) the large foliage-leaves, of which only the bases are shown; (2) the 'axillary shoots' of Stenzel; (3) the small scale-leaves or aphlebiae; (4) the adventitious roots.

The bases of the foliage-leaves are of large size and have a marked effect on the outline of the stem; they are given off at short intervals. The whole form of the stele is, as we have seen, dependent on the course of the bundles supplying these leaves and their axillary shoots. The latter, the nature of which has been somewhat disputed of late (Kidston, '10), are a most characteristic feature, peculiar to the Zygopteris Grayi type among 
known fossil Ferns, but finding a close analogue in recent Hymenophyllaceae Where the trace of a foliage-leaf is to be given off the stelar arm broadens out at the end and acquires two prominent angles or horns (Pl. II, Phots. I I and I2). At the same time the large-celled xylem becomes continuous across the arm, cutting off the peripheral part of the internal xylem, which now forms an island (Phot. I2). When the trace detaches itself from the stele the line of separation passes through the large-celled xylem, which thus forms a closed ring in the leaf-trace, while it also remains closed in the arm from which the trace has parted (Phot. 13). Nothing of the nature of a leaf-gap is formed; a real leaf-gap is of course out of the question, as there is no true pith.

The leaf-trace, immediately on leaving the stele, as shown in Williamson's later specimen, is approximately triangular in transverse section with the base of the triangle outwards (Pl. II, Phot. I3; Pl. IV, Fig. I2). At the two abaxial angles are the groups of small tracheides already mentioned, and in the middle of the strand is the island of internal xylem and parenchyma. The abaxial groups are destined for the foliar bundle, while the central island belongs to the axillary stele.

The phloem closes round the outgoing trace as soon as it becomes detached, so that the bundle assumes concentric structure from the first (Pl. IV, Fig. I2). It may be called the undivided trace, for it represents the common base of the foliar bundle and of the axillary stele. The separation between the two takes place where the trace is passing through the outer cortex, at a level where the base of the leaf is already prominent (Pl. II, Phot. II). The abaxial part of the common trace separates, to form the foliar bundle, the line of separation passing through the largecelled xylem, so that here, as in the departure of the trace from the stele, no gap is left in the strand behind. The foliar strand, as it becomes free, begins to assume the $\mathrm{H}$ form, but at first the shape is rather that of a very flat $\mathrm{W}$ with the base of the letter outwards, for the adaxial are longer than the abaxial 'antennae' and diverge from one another towards the axis (Pl. II, Phot. I2; Pl. V, Fig. I3). The phloem at once completes itself around both foliar bundle and axillary stele; the latter at this level has an almost circular or slightly elliptical transverse section, the major axis in the latter case being tangential with reference to the parent stem (Pl. II, Phot. Io; Pl. V, Fig. I 3) ; the island of internal xylem persists throughout. A little higher up, the stele passes into the cylindrical axillary shoot, where it becomes free. I adhere to the terminology of Stenzel, reserving all morphological questions as to the nature of the leaf-trace and branch for future discussion (p. 57).

The scale-leaves or aphlebiae, discovered by Renault in 1869 in his Zygopteris Brongniartii, and by Stenzel in Zygopteris scandens twenty years later (Stenzel, '89), are seated both on the stem itself and on the base 
of the leaf. They are quite distinct from the foliage-leaves and much more numerous. The small trace supplying each aphlebia traverses the cortex with a steeply ascending course. These bundles, unlike those of the true leaves, have no effect on the general morphology of the stele. On entering the aphlebia the vascular strand undergoes one or more divisions. In calling the scales 'aphlebiae' it is implied that they are of the same nature as the outgrowths borne higher up on the rachis of allied leaves. As Paul Bertrand has stated ('09, p. 109), their vascular strands in Z. Grayi and $Z$. scandens are given off from the leaf-traces ' avant même leur individualisation complète'.

Lastly, there are the adventitious roots; they are much less numerous than the aphlebiae and their steles pass out almost horizontally through the cortex, a fact which enables them to be easily distinguished. The roots, so far as observed, are diarch; the root-stele is inserted laterally on an arm of the main stele near its extremity (see Pl. V, Fig. I4).

The above description would apply almost word for word to the Zygopteris scandens of Stenzel as well as to Williamson's species. Williamson, indeed, when he first saw Stenzel's paper of 1889 , was inclined to assume that the two species were identical (Williamson, '89, p. I57). We shall find that the new specimen from Shore presents some slight differences from the described specimens of both species.

The old genus Zygopteris of Corda, characterized by the $\mathrm{H}$ or double anchor form of the foliar bundle, has been broken up in Dr. P. Bertrand's memoirs, and among the smaller genera created out of it are Ankyropteris (founded as a subgenus by Stenzel but redefined by P. Bertrand) and Etapteris (P. Bertrand, '09, pp. 206, 218 ). The distinction is based on the petiolar structure ; the well-known species $Z$. (Ankyropteris) bibractensis and $Z$. (Etapteris) Lacattii may serve as types of each. Among the most important diagnostic characters of the two genera are :

Ankyropteris. Ramifications of the frond in two series, one on each side of the rachis.

Etapteris. Ramifications of the frond in four series, two on each side. Ankyropteris. Peripheral loops of small-celled xylem permanently present on the flanks of the foliar bundle.

Etapteris. Peripheral loops absent. ${ }^{1}$

Ankyropteris. Adaxial longer than abaxial antennae. Middle band of bundle often curved, with concavity outwards.

Etapteris. Adaxial and abaxial antennae of equal length. Middle band of bundle straight.

The question whether Zygopteris Grayi belongs to Ankyropteris or Etapteris is disputed. Dr. P. Bertrand takes the former view and suggests that the petiole may possibly be identical with Ankyropteris bibractensis,

\footnotetext{
1 Except perhaps temporarily in E. tubicaulis (P. Bertrand, '(9, p. 206).
} 
var. westphaliensis (P. Bertrand, '09, pp. I06, I09). Dr. Kidston, on the other hand, identifies the petiole of $Z$. Grayi with $Z$. di-upsilon, Williamson, which is a typical Etapteris (Kidston, '10). As we shall see, the new specimen is an unquestionable Ankyropteris; as, however, it differs somewhat from those previously described, it does not by itself suffice to settle the point in dispute, and reference to the other specimens will be necessary.

Other questions on which the new specimen throws light are the morphology of the leaf-trace and axillary stele, the structure of the internal xylem, the position of the protoxylem, and the course of the bundles supplying the aphlebiae.

\section{The Shore Specimen.}

We will now go on to describe the Shore specimen. The specimen is from an ordinary seam-nodule and is accompanied by fragments of Lyginodendron, Lepidodendron leaves, and other familiar objects of the coal-balls. In this respect it resembles Williamson's later specimen (see above, p. 39) and the fragment originally described by him in 1874 , while it differs from the specimens on which the species Z. Grayi was founded in 1888 ; the latter were contained in a roof-nodule and are accompanied by Goniatite shells. ${ }^{1}$ This difference may raise a doubt whether all the specimens of the $Z$. Grayi type really belong to one species. The part of the Shore specimen from which my sections were cut was about two inches in length; this piece was cut into twelve transverse and ten longitudinal sections, the latter coming immediately below the former. The transverse series is very good for following the whole process of the emission of the leaf-trace, ${ }^{2}$ but it does not show perfectly the separation between leaf-trace and axillary stele ; the latter, however, is seen very well, both in transverse and longitudinal sections (Pl. IV, Figs. 9 and Io), while the form and structure of the foliar bundle are fairly exhibited, though in oblique section (PI. I, Phot. 9).

The general structure requires no long description, as it is in all essentials of the Zygopteris Grayi type, as recapitulated above. The maximum diameter of the stem is about I $8 \mathrm{~mm}$., that of the wood about $6 \mathrm{~mm}$.

The five-rayed, stellate wood is rather regular in outline, for even the shorter arms are well marked (Pl. I, Phots. I-6). The longer arms, about to give off a leaf-trace, are more conspicuously bicornute than in some other specimens, as corresponds to the form of the leaf-trace itself. A glance at Pl. I, Phots. 4-6, shows that the leaf-trace has a very different form from that in the figured specimens of Z. Grayi or Z. scandens. In these

1 In my review of Dr. P. Bertrand's Études sur la Fronde des Zygoptéridées (New Phytologist, vol. viii, I909, p. 268) I erroneously stated that ' $Z$. Grayi is a roof-nodule fossil'. This is only true of the type-specimens. The correction of this slip removes one objection to Dr. Bertrand's suggested identification of $Z$. Grayi with Ankyropteris westphaliensis; see, however, p. 57.

${ }^{2}$ A selection from the transverse series is shown in Plate I, Photographs $I-6$, running from below upwards. 
cases, as already mentioned, the undivided leaf-trace has a somewhat triangular transverse section, as shown in P1. IV, Fig. I2; in the Shore specimen the section may be described as crescentic (P1. I, Phots. 4-6, 8 ; Pl. III, Fig. I) with the concavity outwards and the ends obliquely truncated. The bundle here, however, is obviously of the same nature as in the Z. Grayi type, for in Pl. I, Phot. I (l.t., a.s.), we see it in the act of dividing to form the axillary stele and foliar bundle, though the latter is imperfectly shown. The form of the undivided trace, though a striking feature of the new specimen, is not peculiar to it; a similar crescentic leaftrace occurs in one of Williamson's type-specimens, as shown in P1. II, Phot. 15 , l.t. The $\frac{2}{5}$ phyllotaxis is obvious on comparing the successive sections (Phots. I-6) and observing the position of the stelar arms from which leaf-traces depart. The phloem and inner cortex are badly or not at all preserved; in this respect the Shore fossil is inferior to the best Williamson specimen (see Pl. IV, Fig. I2 ; Pl. V, Fig. I3). The wide outer cortex has the same general character as in the latter, and is traversed by numerous aphlebia-bundles. In both plants the epidermis bears great numbers of multicellular uniseriate hairs (Pl. IV, Fig. 7). The adventitious roots appear to be given off in the same way in all the specimens (see Pl. V, Fig. I4, from Williamson's later specimen).

\section{Structure of the Stele.}

The general ground-plan of the wood is not at all unlike that in the Williamson type-specimens (Williamson, '89, Pl. I, Figs. I and 2, and P1. II, Phot. I5, in the present paper); the resemblance to his later specimen is not quite so exact (cf. Pl. II, Phots. II-I 3). The central tissue ('mixed pith') has a diameter of little over I mm., and a pentagonal outline (P1. I, Phot. 7). The internal system of tracheides forms an interrupted zone in the outer region of the mixed pith, enclosing a considerable amount of parenchyma (Pl. I, Phot. 7).

Pl. III, Fig. 3, is from a longitudinal section of the stele, cut somewhat tangentially, so that the plane of section coincides with one side of the zone of internal xylem, and several groups of internal tracheides are shown (x.i.).

From the central zone extensions of the internal xylem extend outwards, up each of the xylem-arms, forming the internal rays, the length of which varies according to the level at which the arm is cut. The internal rays are narrow in this specimen and the tracheides in them much compressed. The tangential diameter of the tracheides in the outer part of the internal ray ranges from I2 to $20 \mu$, the radial diameter from 18 to $60 \mu$. Some of these compressed tracheides show a spiral thickening, and no doubt represent the protoxylem of the stele. ${ }^{1}$

1 The protoxylem elements are best shown in the axillary stele. See Pl. IV, Fig. IO, $p x$. 
It is to be noted that the internal tracheides are of the normal elongated form and not short, as in the stem of Diplolabis Römeri described by Dr. Gordon ('11). The parenchyma accompanying the tracheides in the internal rays as well as in the central tissue consists of much-elongated thin-walled cells (Pl. III, Fig. 3).

The tracheides of the internal xylem-zone range from about $45 \mu$ to $100 \mu$ in diameter. The smallest, in the outer part of the zone, sometimes show a spiral thickening (Pl. III, Fig. 3).

The peripheral or main zone of wood consists entirely of large scalariform tracheides from $100 \mu$ to $250 \mu$ in diameter, the larger sizes predominating, if we leave the ends of the arms out of consideration. In the latter region the structure varies greatly according to level, as will be seen on examining any of the Photographs I-6, P1. I. A xylem-arm which has just given off a leaf-trace (arm 5, Phot. 5) shows practically no differentiation; the tracheides at the distal end are scarcely smaller than the others. On the other hand, an arm which is on the point of giving off a trace already has the characteristic leaf-trace structure in its distal part, which is about to become detached (arm 5, Phot. 3, and arm 4, Phot. 6). This structure consists essentially in the presence of peripheral loops, one at each extremity of the bicornute arm, and of an island of internal xylem on the median line (Pl. I, Phot. 8 ; Pl. III, Fig. I). The intermediate arms show the various stages of transition from the undifferentiated to the differentiated structure, as will be explained in describing the process of emission of the trace.

\section{Structure of the Leaf-trace.}

The structure of the undivided leaf-trace is shown in Pl. I, Phot. 8, where it has just parted from the stele, Pl. III, Fig. I, where it has already entered the cortex, and Pl. III, Fig. 2, at a point further out on its course. The trace passes out so gradually that it is seen practically in transverse section throughout. The changes in this part of its course consist in a slight broadening of the middle part of the trace and in a gradual lengthening of the 'antennae', the name given by Dr. Paul Bertrand to the extensions of the xylem forming the lateral bars of the $\mathrm{H}$-shaped foliar bundle in the old genus Zygopteris. At the lowest level (P1. I, Phot. 8) the antennae are scarcely present ; the peripheral loops simply occupy the truncated ends of the lunulate bundle, facing obliquely outwards (cf. Phots. 4 and 5). At the level shown in Pl. III, Fig. I, the antennae already form recognizable protrusions, especially at one end of the bundle; at a still higher level (Fig. 2) they are quite prominent; it will be noticed that at the level shown in Fig. 2 the abaxial is longer than the adaxial antenna, contrary to the usual condition in Ankyropteris (cf. Pl. V, Fig. I3).

The peripheral loop consists of a double or triple band of small 
scalariform tracheides (forming the 'filament' of Dr. P. Bertrand) (PI. I, Phot. 8 ; P1. III, Figs. I and 2, x.e.). At the ends, this band turns round and is continuous with the xylem of the antenna. The narrow space enclosed by the loop is occupied partly by very narrow tracheides, partly by a few elongated parenchymatous cells. The narrow tracheides inside the loop are no doubt the protoxylem; I have detected ill-preserved spiral elements in this position in a longitudinal section. The protoxylem appears to form two groups, one near each end of the loop ( $p x$., Figs. I and 2, Pl. III), probably with one or more intermediate groups as well.

On the inner side the loop is bounded by the ordinary xylem of the antenna, the tracheides in this position being only a little smaller than elsewhere. It will be seen that the structure agrees quite well with that of the peripheral loops in Ankyropteris bibractensis, var. westphaliensis, as described by Dr. P. Bertrand. ${ }^{1}$ The agreement is especially evident where the antennae have become prominent, as shown in Fig. 2.

The external xylem-band or filament sometimes appears to be confluent with the antenna for considerable distances, the interior space of the loop then not being continuous (Fig. 2).

The stages where the leaf-trace is separating from the axillary stele are not well shown in the new specimen. A trace in the act of division is present at l.t., a.s., in the section represented in Pl. I, Phot. I ; the axillary stele is clear, but the foliar strand is much damaged.

In the longitudinal series a foliar bundle is shown in very oblique section (Pl. I, Phot. 9). This is seen some little way above its separation from the axillary stele, which is present in another section of the series (part of this stele is shown in P1. IV, Fig. 10). The foliar bundle represented in Phot. 9 has, in fact, already entered the petiole. Its slender proportions and long antennae agree well with the structure of the bundle in Williamson's original specimens (cf. Pl. II, Phot. I6). The peripheral loop is quite evident, and at once identifies the bundle as that of an Ankyropteris. In the comparative straightness of the middle band ('apolar') and of the antennae the bundle differs widely from $A$. bibractensis, var. westphaliensis, P.B.; the original A. bibractensis of Renault is intermediate in these respects (Renault, '69, Pl. IX).

The swelling on the adaxial antenna, near its junction with the middle xylem-band, marks the presence of a lateral bundle, destined for a secondary rachis (Pl. I, Phot. 9), as is more clearly shown in an adjacent section (2529). So far as can be seen, the mode of emission of the secondary bundle agrees with that described by Dr. P. Bertrand, but the obliquity of the sections leaves the details obscure. At any rate it is clear that the lateral strands were given off singly as in Ankyropteris, and not in pairs as in Etapteris. 
Another characteristic feature of the undivided trace is the presence of a median island or strand of internal xylem, accompanied by parenchyma (Pl. I, Phot. 8 ; Pl. III, Figs. I and 2, x.i). The island has an irregularly elongated shape, and one or more smaller islets may be detached from it (Phot. 8). These, however, die out as the trace is followed upwards, and the median strand becomes more regular. This strand is destined to form the internal xylem of the axillary stele (Pl. I, Phot. I, a.s.; Pl. IV, Fig. 9). I have found it continuous at all levels, both in the Shore specimen and in the best one of Williamson's (Pl. IV, Fig. I2; Pl. V, Fig. I3). The doubt expressed by Dr. Kidston ('10, pp. $\left.45^{2}, 454\right)$ as to the presence of a 'pith' at the place where the axillary stele separates from the leaftrace is evidently to be explained by defects of preservation, as he himself suspected. It must, however, be emphasized that in no case is a true pith present in Zygopteris Grayi, either in the main stele, the undivided leaftrace, or the axillary stele. In all cases the central tissue contains numerous tracheides, as proved by longitudinal as well as transverse sections.

The whole form and structure of the undivided trace in the Shore specimen show that this organ is essentially a leaf-trace rather than the stele of a branch. It constitutes, as already stated, the common base of the foliar bundle and the axillary stele; in the Shore specimen the foliar bundle characters predominate, while in the Williamson specimens, at least those which have been figured, the stele characters are more obvious, so that the whole has been regarded as a branch (compare Pl. III, Fig. I, with Pl. IV, Fig. I2). Such an idea would scarcely have arisen if specimens like that from Shore had first come under observation. The question will be more fully discussed later in the paper (p. 57).

\section{Emission of the Leaftrace.}

The whole process can be followed in the Shore specimen.

If we start with that arm of the stele which has last given off a leaftrace (e. g. arm 5, shown in Pl. I, Phots. 4 and 5) we find that it is short, with a rounded outline, and without any sign of the peripheral loops. The corresponding internal ray penetrates the arm for half its length or more. Otherwise there is little or no differentiation. At a slightly higher level the internal ray extends further outwards, and the tracheides external to its termination become markedly smaller than the rest. The extension of the ray is at first one-sided (see Phot. I, arm I; Phot. 2, arms I and 2; Phot. 6, arm 5). This is the first indication of a peripheral loop. Further up, a second branch of the internal ray appears, so that it becomes forked. The branches very nearly reach the surface, from which they are only separated by bands of small tracheides (Phots. 3 and 4 , arms I and 2). The structure at this level is of much interest, as we here see continuity 
established between the protoxylem of the stem contained in the internal rays and that of the leaf-trace enclosed in the peripheral loops. It must, however, be remembered that the approach of the protoxylem-rays to the surface of the wood is not only connected with the supply of the leaf-trace ; continuity with adventitious roots has also to be established. Root-steles, for example, are given off from arm I at a level between that of Phot. 4 and Phot. 5 .

The condition at a somewhat higher level, in a case not complicated by root-insertions, is shown in detail in Fig. 4, Pl. III. ${ }^{1}$ Here the arm already has a squarer end than lower down. The internal ray (which is still continuous) is expanded, at the point where it forks, into a little triangular body, the first indication of the central strand destined for the axillary stele. Beyond this the two branches of the ray run out nearly to the surface.

Still higher up, the arm becomes cornute; the peripheral loops are lengthened and are here more evident as loops ; they now become isolated, so far as the transverse section is concerned, by the closing up of the branch rays which connected them with the triangular body. This also becomes isolated by the closing up of the internal ray behind it, a change which may take place at a lower level. (See Phots. $3-5$, arm 3 ; for the shutting off of the main ray at a lower level see Phot. 6 , arm $\mathrm{r}$.)

The rest of the process may be followed rapidly in arm 5. At the bottom of the series (Phot. I) this arm has long lobes, each of which is obliquely truncated and tipped by a peripheral loop; the loops are quite cut off from the median triangular strand, but the latter is still in connexion with the internal ray. Above this (Phot. 2) the ray is beginning to die out behind the strand, which is lengthening tangentially. At the next higher level shown (Phot. 3) the ray has completely closed up for a long distance and the median strand appears as an island, surrounded by the large-celled wood. The arm is here distinctly constricted about midway between the island and the end of the internal ray.

Here the trace separates from the wood, as seen in Phot. 4 and Phot. 8. The outward passage of the trace and the slight changes which it undergoes within the limits of the series require no further description.

From the facts observed it is clear that the peripheral loops are constituted by the two branches of the internal ray passing out nearly but not quite to the surface of the wood, the parts which enclose their termination becoming small-celled. The internal rays contain the protoxylem, which thus comes to lie inside the peripheral loops. The point of bifurcation of the internal ray supplies the median strand for the axillary stele. All these parts become isolated as we follow them further up. In other words, the ' undivided leaf-trace' receives three branches from the internal

\footnotetext{
1 Arm 2, from the section next above that shown in Phot. 6.
} 
xylem and protoxylem of the stem; the two distal branches pass into the peripheral loops; the proximal branch takes a median position and ultimately supplies the axillary shoot. Thus the whole organization of the leaf-trace is dependent on the internal xylem of the stem, for it is from this that its first-formed elements are supplied.

\section{Structure of the Axillary Stele.}

As we have seen, the axillary stele is represented in the undivided trace by the median adaxial bulge with its central strand of small tracheides and parenchyma (Pl. I, Phot. 8; Pl. III, Figs. I and 2). The bulge becomes more marked as the trace passes further out (Pl. I, Phot. 6 ; Pl. III, Fig. 2).

At the beginning of the series of transverse sections, the axillary stele seen far out in the cortex is just separating from the leaf-trace, ${ }^{1}$ and its outline is already clearly defined, the line of separation passing through the thick abaxial xylem (PI. I, Phot. I, a.s.). It has a somewhat elliptical central strand at this level. The same stele at a rather higher level, after its complete separation, is shown in Pl. IV, Fig. 9. Allowing for slight damage, the stele is approximately circular in section; the central strand ('mixed pith') has a somewhat angular outline, possibly an indication of its ultimate stellate form. The internal xylem appears to form a solid, rather irregular mass, and has not assumed the annular arrangement characteristic of the main stele. The position of the protoxylem is not easy to determine; some of the smallest elements lie on the outside of the internal xylem, but it is not certain that they all do.

The longitudinal section (Pl. IV, Fig. IO) shows the structure of another axillary stele, no doubt that belonging to the next lower leaftrace. The broad outer zone of scalariform tracheides encloses the strand of small elements forming the internal xylem, and in one part the spiral tracheides of the protoxylem $(p x$.) are evident. They appear to be adjacent to the parenchyma of the central strand, and thus to lie on the outside of the internal xylem.

The axillary stele, in this part of its course, thus shows the stelar structure of the plant in its simplest form. The essential features-peripheral and internal xylem-systems-are present, but none of the complications of form and tissue-arrangement belonging to the fully developed stele have yet appeared.

Some further points connected with the axillary stele will be considered when we return to the Williamson specimens (see p. 54).

1 This is the trace corresponding to arm I of the stem-stele. 


\section{The Aphlebiae.}

Scale-leaves or aphlebiae are borne indiscriminately on the stem and the leaf-bases, unless indeed we regard the whole surface as covered with leaf-bases, an interpretation which the form of the transverse section scarcely seems to justify. The numerous aphlebia-traces which traverse the cortex give the best idea of the number of these appendages (Pl. I, Phot. 4).

The Shore specimen shows several aphlebiae in connexion with the stem, but not many after they become free. Fig. 7, Pl. IV, represents one just detached from the cortex, with which it is connected lower down in the series. There are two gaps in the tissue, symmetrically placed, in one of which a vascular bundle is contained; no doubt the second bundle has been lost. In another case an aphlebia contained three bundles, and there was some evidence of a lateral lobe having been given off. The extreme tangential extension of the bundle in the aphlebiae still attached to the stem (cf. Pl. III, Fig. 6) is no doubt preparatory to division; in some cases the fission had begun.

From the evidence of the Shore fossil and of the second Williamson specimen we may conclude that the aphlebiae were lobed bodies containing as many as three vascular strands-possibly more.

The origin of the aphlebia-trace has been investigated, confirming Paul Bertrand's statement that they are given off from the leaf-traces, even before the complete individualization of the latter. They spring from the arms of the stele below as well as above the point where these become free as definitive leaf-traces. Thus Plate III, Fig. 5, shows an aphlebia-strand just given off from, and still connected with, one of the peripheral loops of a leaf-trace (No. 5) just detached from the stele. The level of the section figured is immediately below that of Phot. 4, Pl. I. On the other hand, in Pl. III, Fig. 4, an aphlebia-strand is shown which has separated from an arm of the stele, still far below the point where the leaf-trace will be given off, and indeed at a level where the peripheral loops are not yet fully differentiated. ${ }^{1}$ The strand is well preserved and appears to show some remains of phloem. Other cases of stele-borne, as distinguished from trace-borne, aphlebia-strands have been observed.

The course of the strand is steeply ascending, as is well shown in the longitudinal section (Pl. IV, Fig. 8), where such a strand can be followed almost the whole way from the stele through the cortex. Numerous aphlebia-strands are given off, in succession, from each leaf-trace or stelar arm. They form four series, two to each peripheral loop.

1 The drawing is from the section next above that represented in Pl. I, Phot. 6, and the arm is No. 2 . 
The text-figure gives a rough idea of the arrangement of six aphlebiatraces, of which the course was actually followed. They are lettered (A-F) in the order in which they were observed to be given off from the leaf-trace 5, to which they all belong. Probably, however, two additional strands from the same end as $\mathrm{C}$ and $\mathrm{E}$ were missed, owing to local damage.

The aphlebia-strand first appears as a bulge of the peripheral loop. On first becoming free its xylem appears to be solid; where any differentiation can be observed, the smallest tracheides are in the middle. As the strand passes further out it becomes tangentially extended, ultimately to an extreme degree, as shown in PI. III, Fig. 6 from the outer part of the cortex of the stem. In this condition the xylem appears to form a flattened

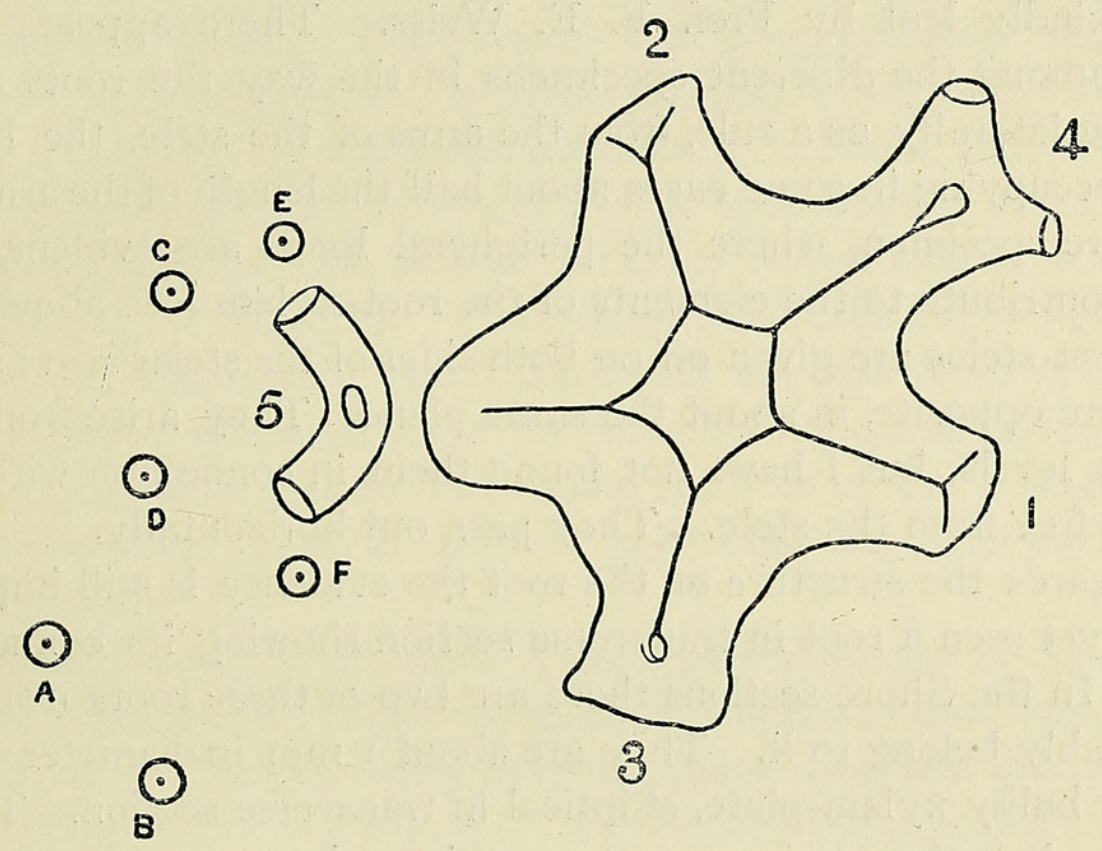

Diagram of stele, with the arms, numbered in kathodic order, the leaf-trace 5 , and the aphlebia-strands (more crowded than in nature) given off from it $(\mathbf{A}-\mathbf{F})$.

ring, with the smallest elements in the interior; in a longitudinal section there was some indication of laxly spiral elements (protoxylem) in this position. It is often noticeable that the tracheides on the abaxial side are larger than those on the adaxial side of the ring, a point of some slight interest, as the same difference exists, in a more marked degree, in the secondary strands of the rachis of Ankyropteris (P. Bertrand, '09, p. 85; Pl. X, Figs. 73 and 74). So far as I have been able to make out, the aphlebia-strands are given off essentially in the same way as the secondary rachis-strands, as described by $P$. Bertrand, i. e. without any interuption of the external xylem ('filament'). There thus seems to be a considerable analogy between the scale-like aphlebiae and the ordinary pinnae of the leaf. 
The conclusions as to the aphlebiae are-

(I) that they are borne on all parts of the stem, without any special relation to the leaf-base ;

(2) that their strands come off from the leaf-trace, both below and above its separation from the stele;

(3) that the protoxylem of the strand is central;

(4) that the strand divides into two or three branches when the aphlebia becomes free.

\section{The Roots.}

Adventitious roots are not very numerous in the Shore specimen; they are better shown in the second Williamson specimen; the illustration on Pl. V, Fig. I4, is from a section of this specimen from the Manchester Museum, kindly lent by Prof. F. E. Weiss. There appears to be no difference among the different specimens in the way the roots are borne. They spring laterally, as a rule, from the arms of the stele, the base of the root-stele occupying in some cases about half the length of the arm (Fig. I4). In the Shore specimen, where the peripheral loops are evident, it is seen that they contribute to the elements of the root-xylem (see above, p. 48).

The root-steles are given off on both sides of the stelar arm; sometimes two roots are opposite, in about the same plane. They arise from the arms at different levels, but I have not found them in connexion with the leaftrace when free from the stele. They pass out horizontally.

As regards the structure of the root the evidence is still imperfect, for I have not yet seen a root in transverse section showing its connexion with the stem. In the Shore sections there are two or three roots near the stem which probably belong to it. They are about $\mathrm{I} \mathrm{mm}$. in diameter and diarch, with a very bulky xylem-plate, elliptical in transverse section. The cortex, if complete, is rather narrow, and sometimes has a pentagonal outline. Quite similar roots are also associated with the second Williamson specimen.

\section{The Williamson Specimens.}

The general description of the structure given in the earlier part of the paper is based essentially on the later Williamson specimen, the most perfect known before the discovery of the Shore fossil, and superior even to the latter in certain respects.

The eight sections of this specimen which I have seen are enumerated on p. 39. I have taken some pains to determine their correct order, which, from below upwards, appears to be as follows :

I. (7) Williamson I9I9 D.

2. (8) " I9I9B.

3. (1) $\quad$ I9I9 C.

4. (2) " $\quad 1919$ A. 
5. (3) Manchester R. 443 .

6. (4) Kidston 308.

7. (5) Williamson $1818 \mathrm{~A}$.

8. (6) Scott 184 .

The only doubt is as to the position of sections I9I9 D and B from the Williamson Collection; it is possible that they should come at the end of the series instead of the beginning. I have given the alternative order in parentheses. No question of importance is involved ; the order of 6 of the sections is certain, and I9I9 B clearly comes next above I9I9 D (see Pl. II, Phots. II and I 2).

The stem is considerably smaller than in the Shore specimen, having a diameter of about $12 \mathrm{~mm}$. as against $18 \mathrm{~mm}$., the wood measuring about $4 \mathrm{~mm}$. as against $6 \mathrm{~mm}$. The arms of the stele are rather shorter in proportion, and when a leaf-trace is detached only a slight protrusion is left (see Pl. II, Phots. II-I3, and compare with Pl. I, Phots. I-6).

In the matter of preservation, the older specimen has the advantage as regards the phloem and the thin-walled inner cortex (see especially Pl. IV, Fig. I2, and Pl. V, Fig. I3). The row of dark cells in the figures cited is probably the endodermis. The outer cortex appears to have thicker walls than in the Shore specimen. On its outer border a few layers of periderm can be recognized in places. The main features of the anatomy need not be further described ; they are evident from what has been said above, and from the figures. ${ }^{1}$

Williamson's second specimen is the typical example of that form of undivided leaf-trace which is approximately triangular in transverse section (Pl. IV, Fig. I2), thus differing widely from the Shore specimen with its crescentic trace (Pl.I, Phot. 8; Pl. III, Fig. I). At one time I thought that this difference might be of specific value. I find, hawever, that among Williamson's typespecimens of 1888 both forms of leaf-trace occur. Thus, an approximately triangular trace is shown in the stem figured by Williamson ('89, Pl. I, Fig. I), while in the stem of which a photograph is given in the present paper (Pl. II, Phot. I5) the trace (l.t.) is perfectly crescentic and agrees closely with those of the Shore plant. Hence, whatever the variation in form may mean, it is impossible to base a specific distinction upon it, for no one will suppose that Williamson's type-specimens, closely crowded together in the same block, belong to two different species. The form of the trace is, however, important, in so far as it has influenced the morphological interpretation of its nature. This question is discussed below (p. 57).

Returning for a moment to the later Williamson specimen, it may be worth mentioning that it differs from the Shore plant in the form of the

1 The anatomy of the stele is shown in my Studies in Fossil Botany, 2nd ed., Fig. I16, p. 3०9. See also Bertrand, '09, Pl. XI, Fig. 78. 
aphlebia-strands. In the latter, these bundles, as they pass out through the cortex, become, as we have seen, much flattened and tangentially extended (P1. III, Fig. 6). The second Williamson specimen shows nothing of the kind; the aphlebia-strands are only slightly elliptical in section, however far out in the cortex they may be. It is possible that the difference may be exaggerated by accidents of preservation, the strands in the Shore plant having to some extent collapsed, but a real distinction, though probably not an important one, certainly remains.

The Williamson type-specimens of 1888 agree in this respect, as in others, with the Shore fossil. The preservation of the cortex is very imperfect; the parts that persist are generally the external margin, the inner margin of the outer cortex, and a margin round the various outgoing strands, including those of the aphlebiae (Pl. II, Phot. I5). It is, however, evident that the aphlebia-strands are much flattened in the outer part of their course.

The type-specimens appear to be of the same variety or form as the Shore fossil, though the former came from a roof-nodule and the latter from a seam-nodule. The largest stem in the type is about $22 \mathrm{~mm}$. in diameter, with the wood measuring $6 \mathrm{~mm}$. The form of the stele agrees very closely (compare Pl. I, Phots. I-6, with Pl. II, Phot. I5); as we have seen, crescentic leaf-traces occur in both and the aphlebia-strands are alike. There can be no doubt on the evidence that the new specimen belongs to the true $Z$ ygopteris Grayi, as founded by Williamson on the 1888 specimens. His later specimen, as we have seen, is a little different in detail, but not, as it seems to me, sufficiently so to warrant specific distinction.

Williamson's later specimen shows some points of interest as regards the axillary stele. The mode of separation between this stele and the foliar bundle is rather different from that shown in the Shore plant. In the latter, as we have seen, the undivided trace is a massive structure, and when the adaxial bulge is to be cut off as the axillary stele the line of separation simply passes through the thick band of the abaxial xylem (Pl. I, Phot. I, l.t., a.s.). In the other, the xylem is narrow and has to be thickened up by the addition of more tracheides, before separation can take place (Kidston, '10, p. 452 ; Pl. XXXIV, Figs. 3 and 4). Thus the formation of a gap in the xylemband is avoided. Further, the axillary stele bears a much larger proportion to the foliar bundle at the point of separation than in the Shore plant. The stele and bundle a little above their severance are shown in Fig. I3, Pl. V. The structure of the stele is the same as at the corresponding level in the Shore specimen, but the phloem is well preserved, forming a ring round the xylem, and conspicuous by its large sieve-tubes. So far there is no indication of lateral appendages.

In Phot. Io, Pl. II, the stele is shown further out in its course, where the axillary branch is nearly free. Here the internal xylem is 
laterally extended, forming a band coincident with the major axis of the elliptical section, and tangential to the parent stem. The row of internal tracheides almost reaches the surface at either end of the band, while the main zone of xylem appears divided into two arcs; the large sieve-tubes are now limited to the adaxial and abaxial arcs, and are absent opposite the ends of the internal band. The structure strongly suggests that leaf-traces, distichously arranged, are about to be given off. The bilateral anatomy of the axillary shoot at this level presents the closest analogy with that of the stem in some recent Hymenophyllaceae, especially Trichomanes radicans and T. reniforme (Boodle, '00, Pl. XXVI, Figs. 22 and 24).

Unfortunately, in the section next above that from which Phot. Io was taken, the axillary stele is destroyed; in the second section above, it is seen in oblique section and not quite complete $;^{1}$ it shows a relatively large 'mixed pith', with at least four prominent angles, and corresponding groups of internal tracheides; on the adaxial side, corresponding to one of the protrusions of the central tissue, there is a projecting arm or incipient leaftrace, with an evident island of internal xylem near its end. It is thus clear that at this level the axillary shoot was already preparing to assume mature structure, with leaves in several series $;^{2}$ the distichous stage, indicated at a lower level, must have been passed through very rapidly. Intermediate conditions between that of the axillary stele (as seen at its base) and the normal stellate form have been previously figured by Williamson ('88, Pl. I, Fig. 5, see p. I57) and Stenzel ('89, Taf. VI, Fig. 53; see '96, p. 7I).

\section{Zygopteris Grayi an ANkyropteris.}

We have seen that the Shore fossil is clearly an Ankyropteris, as shown by the manifest presence of the peripheral loops, characteristic of that genus, on the leaf-trace, confirmed by such slight indications as we have of the arrangement of the pinnae on the rachis (see above, p. 46).

The question remains whether the Ankyropteris characters are common to all the specimens known. Dr. P. Bertrand includes the plant in Ankyropteris, and in his description, based immediately on the later Williamson specimen, he states that the leaf-trace has two poles, interior to the reod, on its posterior (abaxial) side, situated exactly at its extremities. He adds that, after the separation of the axillary strand, each of the poles divides into two, and that this division is the point of departure of the formation of two peripheral loops (Bertrand, '09, pp. 108, 109).

In a letter dated September 25, I9I I, Dr. Bertrand informed me that

1 The three sections are W. I9I9 A, R. 443, and Kidston 308. See list above, p. $5^{2}$.

2 It is interesting to find that in this section (Kidston 308) the cortex of the axillary shoot contains several aphlebia-bundles, which are absent from it at a lower level. Evidently, as soon as the first leaf-traces of the shoot began to be differentiated, the inevitable aphlebia-strands appeared with them. 
he had strong reasons for believing that Williamson's type-specimens also belonged to Ankyropteris. He sent me photographs of Williamson's section I824, showing that a petiole of the plant had evident peripheral loops I at once consulted the original section, and satisfied myself that this is the case. The section has been rephotographed by Mr. Tams, and is shown in Pl. II, Phot. I6. The petiole in question is a perfectly typical one of $Z$. Grayi, and, as Dr. Bertrand pointed out to me, is identical with the petiole of which another section is figured by Williamson ('89, Pl. I, Fig. 4). There is little doubt that this petiole belongs to one of the associated stems.

A glance at Phot. I 6 will show that the band of small elements forming the external xylem (x.e:) of the peripheral loop is perfectly evident, especially on the left-hand side.

The proof that Williamson's type-specimens of Zygopteris Grayi belonged to the genus Ankyropteris, as now defined, is entirely due to Dr. P. Bertrand, to whom I am much indebted for calling my attention to the critical section.

The difficulty is greater in the case of the later Williamson specimen. The preservation of this specimen, good as it is for most purposes, is such as to render it difficult to make out the arrangement of the small external tracheides. When I described the structure of this stem in my 'Studies in Fossil Botany', I was inclined to regard these elements simply as protoxylem. On a careful re-examination of all the sections, I have observed cases where peripheral loops appeared to be present on the leaf-trace, but scarcely any were absolutely decisive, as it was seldom possible to distinguish with certainty between the supposed elements of the external xylem ('filament') and those of the protoxylem on the one hand or the inner phloem on the other.

The leaf-trace shown in P1. II, Phot. I4, seems, however, fairly conclusive. The position of this bundle (l.t.) relative to the stele is shown in the general sketch, Fig. I $5, \mathrm{Pl}$. V. One corner of the trace is obliquely truncated, recalling the leaf-traces of the Shore specimen. The truncated end is coated by a band of small elements, apparently tracheides (see Pl. II, Phot. I4, x.e., and the slightly diagrammatic drawing of the same in Pl. IV, Fig. II, x.e.). The appearance is remarkably like that of one of the peripheral loops of the Shore specimen, though of course less clear (cf. Pl. I, Phot. 8, and Pl. III, Fig. I).

Taking the whole of the evidence into consideration, I feel no doubt that Dr. P. Bertrand was right in his interpretation, and that this specimen, like the others, has peripheral loops and is therefore an Ankyropteris. As we have seen, this conclusion is now established as regards the Shore fossil and the type-specimens of Williamson; I believe it may safely be extended to all specimens of the $Z$. Grayi type. 
I think it probable, however, that there was a slight difference between the later Williamson specimen and that from Shore, the peripheral loops not becoming clearly differentiated so low down in the course of the leaf-trace in the former as in the latter. Dr. Bertrand's own description clearly points to a rather late differentiation in this respect.

The petiolar bundle of the type-specimens (PI. II, Phot. I6) is almost identical in form with that of Zygopteris di-upsilon (Williamson, '80, Pl. XXI, Fig. 90), with which Dr. Kidston identified Z. Grayi (Kidston, '10). The resemblance is so striking that this conclusion appeared well founded at the time. Dr. Kidston, like myself, had not then recognized the presence of peripheral loops in Z. Grayi. Z. di-upsilon is a typical Etapteris (P. Bertrand, '09, p. I48; P1. I, Fig. 6; Pl. XVI, Fig. IIO), and, as such, has no peripheral loops and gives off four series of secondary strands from the foliar bundle. It cannot therefore belong to Zygopteris Grayi, which is shown to be an Ankyropteris by the presence of peripheral loops, and by there being (so far as the available evidence shows) only two series of secondary rachis-strands.

Dr. P. Bertrand ('09, p. I06) suggested, with much reserve, the possibility that the petiole of $Z$. Grayi might be identical with the well-known $Z$. bibractensis, var. zestphaliensis. The differences in the form of the foliar bundle are obvious ; the middle band of the xylem ('apolar') is straight in $Z$. Grayi, curved in $Z$. westphaliensis; the lateral bands (antennae) are long and but little curved in $Z$. Grayi, while in $Z$. westphaliensis they are strongly bent inwards towards the plane of symmetry; further, the antennae are of approximately equal length in $Z$. Grayi, while in $Z$. westphaliensis those on the convex (presumably adaxial) side of the median band are considerably longer than those on the concave (abaxial) side. Nothing has yet been observed to indicate that the one form passed over into the other, and there is a strong presumption that the species are distinct.

\section{The Morphology of the Leaf-trace and Axillary Stele.}

There are two views of the nature of the organ which throughout this paper has been called the 'leaf-trace' or the 'undivided trace'. On the one view, which was that of Stenzel, ${ }^{1}$ the first to observe the facts, this strand is essentially a leaf-trace, directly continuous with the foliar bundle, but modified, to a certain extent, by the presence of a branch, the stele of which is given off from the leaf-trace on its adaxial side and a little above its base. From its position the branch is consistently termed the axillary shoot, and its vascular strand the axillary stele.

On the alternative view, the meristele which we have called the leaftrace is, from its base, of an axial nature, constituting the stele of a branch ; the true leaf-trace is given off from it as a lateral appendage. On this

$$
1 \text { ' } 89 \text {, p. } 35 \text {; ' } 96 \text {, p. } 3 \text { I. }
$$


interpretation there is no ' axillary' organ at all ; the branching is regarded as an unequal dichotomy, of which the main stem and the smaller (so-called 'axillary') shoot are the two limbs. The leaf associated with the smaller branch is the first appendage of that branch and not its subtending organ.

This interpretation was mentioned by me in $1908^{1}$ as a possible one ; I then regarded the data as insufficient to settle the question. Dr. Kidston ('10, pp. 45 1,454$)$ has adopted this view ; he speaks of our ' undivided leaftrace' as a 'branch', and describes the petiole trace as an independent organ arising from the periphery of the 'branch' (i. e. branch-stele).

The interpretation of the branching of $Z$. Grayi as a dichotomy is supported by the analogy of $Z$. corrugata, in which, to all appearance, a real and equal dichotomy of the stem and its stele occurs. ${ }^{2}$

After the investigation of the Shore specimen of $Z$. Grayi, I can no longer regard the question of the morphology of these organs as an open one. The evidence of that specimen seems to me decisive in favour of the view that the meristele, from its base upwards, is a leaf-trace. The peripheral loops are essential parts of the leaf-trace or foliar bundle; they have nothing to do with the stem or its branches. Now we have seen that in the Shore specimen the peripheral loops are already fully differentiated where the meristele first becomes free from the stele, and even at a considerably lower level. It is impossible any longer to contend that an organ with these characteristic foliar structures can be of the nature of a branch. The general form of the meristele further supports the obvious leaf-trace interpretation. What is true of the Shore specimen must moreover hold good for the other specimens also. In the type specimens, as we have seen, leaf-traces of the same form as those of the Shore fossil occur. In the later Williamson specimen the form of the meristele is different, and the peripheral loops perhaps differentiated later; they exist, however, where the meristele is still undivided; the relation of the meristele to the main stele on the one hand and to the axillary stele and foliar bundle on the other is the same as in the Shore plant.

It thus seems to be established that in $Z$. Grayi the meristeles given off from the arms of the stem-stele are leaf-traces, altogether homologous with those of $Z$. corrugata or Diplolabis Römeri. With the former plant especially, there is a close agreement in the mode of emission of the leaftrace, if we allow for the difference in the form of the stele from which it is given off (P. Bertrand, '09, p. I IO; Pl. XII, Figs. 87-9).

1 Studies in Fossil Botany, 2nd ed., p. $3^{18 .}$

2 This seems to be rare. I only know of one specimen (to be described fully in a forthcoming paper) which shows the branching in this species. Dr. Kidston's citation ('10, p. 454) of the brief reference to the fact in my Studies (p. 3 I 8 ) might be understood to imply that I regard the leaf-traces in $Z$. corrugata as of the nature of a dichotomy. This is not, of course, the case; the forking of the stem involves an equal division of the stele and has nothing to do with the wellknown process of the emission of a leaf-trace. 
The conception of the meristele as a leaf-trace keeps the Zygopteris Grayi type in line with all the other Zygopterideae, and is in agreement with all the facts, as, for example, with the $\frac{2}{5}$ phyllotaxis.

On the branch interpretation, the arrangement of the appendages would not be a phyllotaxis at all, but a caulotaxis-a system of dichotomies in which the successive smaller limbs followed a $\frac{2}{5}$ divergence-a strange phenomenon for which we should be puzzled to find an analogy. Also, the branch theory would compel us to assume that the main stem was leafless, or restricted to scale-leaves (like a Pinus), while the foliage-leaves were limited to the lateral branches or smaller limbs of the dichotomy. All these are sufficiently improbable assumptions where Ferns are concerned, and, even without the evidence of the Shore specimen, would almost drive us to accept the simple and intelligible view that the leaves are borne directly on the stem.

What then are we to make of the axillary branch? Although it certainly does not give rise to the leaf-trace it must undoubtedly have some effect on the structure of the latter in the basal region. In the case of Williamson's later specimen especially, the effect is very marked, disguising to a considerable extent the leaf-trace character of the meristele ; it led to the whole organ being regarded as the stele of a branch. In the Shore specimen, on the other hand, as we have seen, the leaf-trace characters predominate throughout, and the presence of an axillary shoot is only indicated in the meristele by a slight adaxial bulge and by the median island of internal xylem. It is not even certain that the latter is necessarily connected with the axillary stele, for a very similar central island appears in the leaf-trace of $Z$. corrugata, which has no axillary stele (P. Bertrand, '09, Pl. XII, Fig. 88); in this case, however, it soon dies out.

We may, if we like, regard the axillary stele as 'adherent' to the adaxial side of the leaf-trace, but this is a mere phrase and throws no new light on the facts.

The analogy with the axillary branching of the Hymenophyllaceae has been often insisted on (see especially Boodle, '00, p. 487), and appears to be a very close one. In the recent family the axillary shoot is sometimes abortive (Chambers, '11), and possibly, as Stenzel thought, this may also occur in $Z$ ygopteris, though certainly not as a rule.

Axillary branching also takes place occasionally in Ophioglossaceae (Botrychium, Holle, '75, p. 313, Taf. III, Fig. 4 ; Helminthostachys, GwynneVaughan, '02). Judging from sections kindly shown me by my friend Prof. W. H. Lang, F.R.S., there seems no doubt that here also there is a decided analogy with the fossil forms. ${ }^{1}$ It is interesting that the axillary branching occurring in Zygopteris should find its parallel in two recent

1 Professor Gwynne-Vaughan's suggestion that the axillary organs which he found in Helminthostachys were rudimentary branches appears to be fully confirmed by Professor Lang's observations. 
families with which an affinity has been recognized by most investigators, from Renault onwards.

Though the branching of Zygopteris Grayi and its allies is not a dichotomy, it may have originated from a dichotomy, the association of the smaller branch with a subtending leaf being a derivative condition. On this view the equal dichotomy of $Z$. corrugata would be the more primitive state, as seems natural. On the other hand, it is not impossible that the case of $Z$. corrugata may be one of modified axillary branching. I hope to return to this question in a subsequent paper.

\section{The Morphology of the Aphlebiae.}

Both Renault and Stenzel regarded the scale-leaves which they discovered in Zygopteris Brongniartii and $Z$. scandens respectively as abortive or reduced leaves, and therefore as comparable to the normal foliage-leaves of the plant. This view is no longer tenable. In Z. Grayi, as we have seen, the scale-leaves (aphlebiae) occur on the leaf-base as well as on the stem; their vascular strands are given off from the leaf-traces of the foliage-leaves and are not independent leaf-traces. Dr. P. Bertrand's view that the scales have the value of secondary petioles seems fully justified (P. Bertrand, '11, p. 53). Their vascular strands are included by him under the name 'sorties hâtives', i. e. they are secondary strands given off ' in a hurry' or below the point where the normal pinnation of the leaf begins. We have seen above that the structure of the aphlebia-strand is not unlike that of the secondary or tertiary rachis-strands in allied species, and that its mode of emission appears to be the same. The aphlebiae, then, are best regarded as modified pinnae of the leaf which have spread downwards on to the stem, but are always in definite relation, by their vascular strands, with the leaf-traces. ${ }^{1}$ That they are modified is shown by the fact that their lamina contains two or three bundles (resulting from the division of the single supply-strand), while in all allied plants the normal pinnae are monodesmic. The function of the aphlebiae may have been a transitory one, the protection of the growing points and young leaves; in fact, they may well be analogous to bud-scales, which are often of the nature of stipules. The aphlebiae themselves might be described as multiple stipules.

Dr. Bertrand's observations appear to have cleared up the mystery which once hung about these curious organs; we need no longer feel tempted to interpret them as representing an ancestral form of foliage such as the phylloids of Lignier, which hypothetically once covered the thallus before its differentiation into stem and frond.

It is very interesting to find that aphlebiae have now been discovered

1. It is true that the aphlebia-strands are given off in two rows from each peripheral loop of the trace (unlike the pinna-strands of the Ankyropteris leaf); no two aphlebia-bundles, however, appear to be given off at the same level. 
by Dr. Margaret Benson ('11) in a species of Botryopteris, B. antiqua, in which they are found to be associated with the simpler monarch form of petiole, which in this species alternates with the larger diarch petioles. These remarkable organs were evidently very widely spread among the Primofilices; how far they were truly homologous with the aphlebiae, so well known in their external form on impressions of the frond in other Palaeozoic Ferns and Pteridosperms, can only be determined when the structure of the latter has been further investigated.

\section{Affinities.}

There are two other species of the same type as Zygopteris Grayi, namely, the $Z$. scandens of Stenzel and the $Z$. Brongniartii of Renault. The former is so closely similar to our species that Williamson thought it the same, and no one has yet found thoroughly satisfactory distinctive characters, though the horizons are so far apart (Lower Coal Measures and Permian) that specific identity is improbable. Dr. Kidston ('10, p. 455) enumerates several points of difference, but some of these are only distinctive on the assumption that Zygopteris (Etapteris) di-upsilon is the petiole of $Z$. Grayi, which, as we have seen, cannot be the case, the latter being an Ankyropteris. From sections of $Z$. scandens in my possession I have not been able to find constant distinctions ; possibly a reinvestigation of the type-specimens might lead to a more definite result. It appears to be commonly admitted that $Z$. scandens is an Ankyropteris; this is probably the case, though the evidence is much less direct than is now the case with $Z$. Grayi; here, again, a further investigation of Stenzel's plant is desirable, though the close agreement with Williamson's species leaves no real doubt as to the genus being the same.

$Z$. Brongniartii, Ren., differs from the other species in the form of the stele, in which the angles are not at all prominent (Renault, '69, P1. III, Fig. I). This seems a well-marked distinction, though Stenzel ('96, p. 3I) thought that all three species might be referable to one. There appears to be no independent evidence to show whether $Z$. Brongniartii is an Ankyropteris. There is a probability that it is so, but at present this only rests on the general similarity to $Z$. Grayi in structure and mode of branching.

Zygopteris corrugata, on the other hand, is certainly a typical Ankyropteris, as Dr. Bertrand has shown, but differs from $Z$. Grayi in its cylindrical stele, dichotomous branching, and other points.

The stem of the Lower Carboniferous Metaclepsydropsis duplex, of which a full description by Dr. Gordon (' $11^{2}$ ) has just appeared, bears a general resemblance to that of Ankyropteris corrugata, the tracheides of the internal xylem being here also associated with parenchyma. Another Lower Carboniferous plant, Diplolabis Römeri, of which Dr. Gordon has given an 
exhaustive and admirable account (Gordon, '11), has a solid xylem without any parenchyma, but there is a marked differentiation between the inner and the outer xylem; the former consists of smaller elements, which are quite short, and presumably served for the storage rather than the conduction of water. The complex structure of the petiole shows beyond doubt that the plant is a Zygopterid; Dr. Gordon regards the stem-structure as the most primitive yet known in the family. So far as the solid xylem is concerned this may well be true; in the shortening of the internal tracheides, however, Diplolabis shows a differentiation not yet observed in Ankyropteris, where these elements are, usually at least, of the ordinary elongated form. Also, as Dr. Gordon has pointed out, Diplolabis and Metaclepsydropsis have quadriseriate pinnae, while in Ankyropteris they are biseriate. It therefore appears that these three genera cannot belong to the same direct line of descent. Dr. Gordon's suggestion (Gordon, ' $11^{2}$ ) that Diplolabis and Metaclepsydropsis led on to Zygopteris Grayi involved the assumption that the latter species is an Etapteris, whereas, as we have seen, it belongs to Ankyropteris. Of the stem of Etapteris we know nothing as yet.

I am inclined to agree with Dr. Gordon's general line of argument in deriving the stem-structure of Zygopterideae from a simple protostele like that of Botryopteris, though, as we shall see presently, Dr. P. Bertrand takes a totally different view of the relationships. ${ }^{1}$

The most interesting comparison, perhaps, is that between Ankyropteris Grayi and Asterochlaena, a genus very imperfectly known until I9II, when Dr. P. Bertrand published a magnificent monograph on the Permian species Asterochlaena laxa, Stenzel. This fine fossil is on a much larger scale than our Ankyropteris, the stem (apart from the leaf-bases) reaching $50 \mathrm{~mm}$. in diameter. The xylem, as is well known, is of the most extreme stellate form, with long spidery arms. The number of xylem-arms at the periphery of the star ranges from eight to thirteen; they anastomose towards the centre. There is, however, no relation between the form of the star and the phyllotaxis, for each xylem-arm gives off two or three series of leaftraces; the arrangement of the bi- and tri-lobed arms is irregular; a unilobed arm has only once been observed with certainty. The number of orthostichies ranges from twenty to twenty-seven; in some specimens the phyllotaxis is whorled, in alternating verticils of ten or eleven members; in the others it is described as 'subverticillate', the number of orthostichies being uneven.

In spite of these striking differences from Ankyropteris, many equally remarkable points of agreement exist. There is a 'mixed pith' at the centre of the star, and from this, median protoxylem-bands radiate, passing up the middle of each arm; where the arm forks the protoxylem-bands

1 The discussion of the curious stem of Zygopteris Kidstoni (P. Bertrand, '11, p. 55), which is described as having a stellate solid xylem, will be best postponed till fuller information is available. 
form a triangle. Dr. Bertrand believes that the median protoxylem-bands are in connexion with the protoxylem which passes out in the peripheral loops of the leaf-traces, though the connexion is often obliterated. The true protoxylem elements are accompanied by narrow scalariform tracheides, exactly as in Ankyropteris Grayi. There is, however, a difference in the fact that short, globular tracheides are also present in the 'mixed pith' of Asterochlaena; I have not found these in our plant.

Roots are inserted laterally on the leaf-trace, just where it leaves the stele, but they also occur on other parts of the xylem-arms. The structure of the roots exactly agrees with that of the roots associated with Ankyropteris Grayi.

The outgoing leaf-trace gives off numerous lateral strands, which pass out in advance of the trace itself. Dr. Bertrand ('11, p. 53) points out the manifest agreement with the strands in Ankyropteris which supply the scales (aphlebiae). In both cases the organs thus supplied have the value of secondary petioles.

Asterochlaena might be described as a multiple Ankyropteris, for it differs most essentially from such a plant as Ankyropteris Grayi in the fact that each arm of the stele supplies two or three vertical series of leaf-traces instead of one.

Dr. Bertrand, it is true, does not recognize so close an agreement between the two genera as seems to me to exist. He states (p. 50 ) that the Asterochlaenas are the only known Ferns which possess a system of protoxylem-bands proper to the stem. It seems clear that Ankyropteris Grayi and its allies are precisely in the same position. He also gives an interpretation of the Ankyropteris vascular system which separates it from Asterochlaena. In $A$. Grayi he regards the wood as constituted of five curved plates, concave outwards, the five ' réparatrices', each of which represents the left-hand 'demi-réparatrice' of one xylem-arm and the right-hand 'demi-réparatrice' of the next ('11, p. 52, Fig. 8 ; see also the text-fig. in this paper, p. 5I). These 'réparatrices' alternate with the 'génératrices foliaires' (vertical lines of leaf-traces). On this view each leaf-trace is supposed to be supplied by the two xylem-bands lying to the right and left. In Asterochlaena, on the other hand, the simple 'réparatrices' are placed directly behind the 'génératrices' in the same radial plane (p. 53). Personally I can see no distinction in this respect, except that the xylem-arms are longer in Asterochlaena.

This whole conception of the Ankyropteris stele seems to me defective, for it ignores the internal xylem, which here, just as in Asterochlaena, ' represents, as it were, the skeleton of the xylem-star' (P. Bertrand, '11, p. 36).

The object of Dr. Bertrand's somewhat artificial interpretation of Ankyropteris structure appears to be to bring it into line with the vascular 
system of Osmundaceae; probably, however, the relation is too indirect for any such detailed comparison to be admissible.

Finally, some reference must be made to Dr. Bertrand's theory of the general course of evolution of the Zygopterideae.

Asterochlacna, though complex in the structure of the stem, has a simple form of petiolar bundle, the xylem forming a curved band, concave towards the stem, with a peripheral loop, containing the protoxylem, near each end, and slightly towards the abaxial surface. The only simpler foliar bundle of this group is that of Clepsydropsis, which is straight, and is thus symmetrical about two planes, while the bundle in Asterochlaena is only symmetrical about one plane (the radial).

Dr. Bertrand ('08) believes that Clepsydropsis is the petiole of Cladoxylon, though the two have not been found in connexion, and the proof is still incomplete. Cladoxylon has a very peculiar polystelic structure, the steles having, on the whole, a radiating arrangement. Dr. Bertrand holds that the xylem-star of Asterochlaena was probably derived by condensation from the dispersed xylem-system of Cladoxylon. A greater condensation, he adds, would clearly give rise to a solid or annular mass of wood with a circular contour ('11, p. 54). Both in Diplolabis Römeri and Ankyropteris corrugata he derives the circular xylem from a stellate xylem by condensation.

He appears, however, to regard the Ankyropteris Grayi type not as an intermediate stage of condensation, but rather as a specially high form of differentiation (see p. 56). He supposes that phenomena of condensation have occurred simultaneously in all the parallel series of the family. The more highly differentiated members may be expected to show-

(I) a solid xylem,

(2) a continuous xylem-ring, or

(3) a xylem-ring differentiated into alternate reparatory and leafgenerating regions, this being the highest type of all.

In the more primitive members of the family, on the other hand (i.e. those nearest to Clepsydropsis), we shall be likely to find a stellate vascular mass. Dr. Bertrand enumerates Diplolabis, Tubicaulis (which has a protostele), and Ankyropteris among the advanced Zygopterideae, Asterochlaena and Zygopteris Kidstoni among the primitive forms.

I do not propose to discuss this interesting theory in detail; a better opportunity may be found in a future communication. It is necessary, however, to point out that two opposite views are held: Dr. Bertrand's theory of condensation from a primitive polystelic structure, and Dr. Gordon's theory (shared, I believe, by most palaeobotanists) of the gradual elaboration of an undifferentiated protostele. Dr. Bertrand's view really depends on the truth of his attribution of the simple petiole Clepsydropsis to the complex stem Cladoxylon; it will scarcely command general assent until this identification has been placed beyond doubt. 
In the meantime it seems to me to be established that a somewhat close affinity exists between the genera Ankyropteris and Asterochlaena. We cannot of course derive one from the other ; Ankyropteris has advanced along the line of high differentiation of the petiolar strand, while Asterochlaena is distinguished by the complexity of the vascular structure in the stem.

\section{Summary.}

I. Zygopteris Grayi is a member of the genus Ankyropteris, as shown especially by the presence of peripheral loops on the leaf-trace. The resemblance of the petiole to Zygopteris (Etapteris) di-upsilon is therefore illusory.

The opinion of Dr. P. Bertrand is thus confirmed.

2. The protoxylem of the stem is situated in the internal rays of the xylem-arms, and passes out thence into the peripheral loops of the leaftrace, which are differentiated before the trace leaves the stele.

3. The protoxylem of the axillary stele is likewise directly continuous with that of the internal rays of the main stele.

4. The undivided leaf-trace or meristele is, from its base upwards, of the nature of a foliar strand and not of a branch-stele. Its structure is, however, affected to a varying extent by the presence of the axillary stele. tomous.

5. The branching is rightly described as axillary rather than as dicho-

6. Internal xylem is always present, both in the main and the axillary stele. There is at present no evidence for the existence of a true pith, without internal tracheides, in any member of the Zygopterideae.

7. Aphlebiae occur abundantly both on the stem and the leaf-base. Their strands are given off from the leaf-traces both below and above their departure from the stele.

8. The aphlebiae are modified basal pinnae of the leaf, as shown by the structure and mode of origin of their vascular strand. The free aphlebia, however, contains two or three vascular strands, which are branches of the original one.

9. Ankyropteris, and especially $A$. Grayi, shows a close affinity with the genus Asterochlaena, the latter differing from the former chiefly in the presence of more than one series of leaf-traces in connexion with each arm of the stele.

I0. The vascular system of Ankyropteris is regarded as probably a highly elaborated protostele, rather than as a condensation of a polystelic structure.

For the loan of sections or photographs I am indebted to my friends Dr. R. Kidston, F.R.S., Prof. F. E. Weiss, and Dr. P. Bertrand, to whom I wish to express my warm thanks. 
The photographic illustrations are for the most part the work of $\mathrm{Mr}$. W. Tams, but some were taken for me long ago by my friend Mr. L. A. Boodle.

The drawings reproduced in Plates III to $\mathrm{V}$ are partly by $\mathrm{Mr}$. G. T. Gwilliam, partly by Miss G. C. Harrison.

To all these collaborators I am greatly obliged for their aid.

\section{APPENDIX.}

It may be of interest to reproduce Williamson's MS. description of the sections of his later, unpublished specimen. The original notes are accompanied by rough sketches to which the letters refer. I am indebted to Dr. F. A. Bather, F.R.S., for a copy of this passage, from the Williamson Catalogue, preserved in the British Museum (Natural History):

' 18 i 8 A. R[achiopteris] Grayii. The most perfect section yet obtained. To be figured. Oldham. Lomax.

I919 A. Rach. Grayii. Trans. Section of a second specimen free from the abnormal mineralization of the specimens previously described. Structure of its secondary branches distinct. Oldham. Lomax.

I919 в. Rach. Grayii. Trans. A second section of I9I9 A, showing some marked features. The extremity of each of the five radii on the transverse section of the axial bundles is square, $a$. In another radius this square end is detached, $b$; in another ray this latter section seems to have divided into two, the "Axilspross", $c$, and the Zygopteroid petiole, $d$. It is thus evident that these two structures spring from the main vascular axis of the stem as a single bundle, $a$ and $b$, but that they divide as they ascend into $c$ and $d$. Stenzel says it is so with his $Z$ ygopteris scandens, but he thinks that the primary bundle is a Zygopteroid one from which the "Axilspross" is a secondary branch. This is not the case in my specimen. He also thinks that the "Axilspross" is an abortive bud. I doubt this. Oldham. Lomax.

1919 c. Rachiopteris Grayii. Trans. A third section of the same with one secondary branch entirely free and a second one just separating from the central axis. Oldham. Lomax.

I9I9 D. Rachiopteris Grayii. Trans. A fourth section from the above specimen. Lomax.'

\section{REFERENCES.}

Benson ('11) : Margaret Benson, New Observations on Botryopteris antiqua, Kidston. Ann. of Bot., $x x v$, p. 1045 .

P. Bertrand ('08): Paul Bertrand, Sur les stipes de Clepsydropsis. Comptes Rendus, Nov. i6, 1908.

('09): Études sur la fronde des Zygoptéridées. Lille.

('11): Structure des stipes d'Asterochlaena laxa, Stenzel. Mém. de la Soc. Géologique du Nord, t. vii. I. 
Boodle ('00): L. A. Boodle, Comparative Anatomy of the Hymenophyllaceae, Schizaeaceae, and Gleicheniaceae. I. On the Anatomy of the Hymenophyllaceae. Ann. of Bot., xiv, p. $45^{\%}$. Chambers ('11): Helen S. Chambers, The Vestigial Axillary Strands of Trichomanes javanicum, Bl. Ann. of Bot., xxv, p. IO37.

Gordon ('11): W. T. Gordon, On the Structure and Affinities of Diplolabis Römeri (Solms). Trans. Royal Soc. of Edinburgh, xlvii, Pt. iv (No. 24).

$\left(11^{2}\right)$ : On the Structure and Affinities of Metaclepsydropsis duplex (Williamson). Ibid. xlviii, Pt. i (No. 8).

Gwynne-Vaughan ('02): D. T. Gwynne-Vaughan, On an unexplained Point in the Anatomy of Helminthostachys zeylanica. Ann. of Bot., xvi, p. I 70.

Holle ('75): H. G. Holle, Leben, Bau und Entwickelung der Vegetationsorgane der Ophioglosseen. Bot. Zeitung, Jahrgang xxxiii, pp. 24I $, 265,28 \mathrm{I}, 297,3^{\mathrm{I}} 3$.

Kidston ('10) : R. Kidston, Note on the Petiole of Zygopteris Grayi, Will. Ann. of Bot., xxiv, p. 45 I.

Renault ('69). B. Renault, Étude du quelques végétaux silicifiés des environs d'Autun. I ${ }^{\mathrm{e}}$ Étude sur la tige de Zygopteris. Ann. des Sci. Nat., Bot., t. xii, p. I6I.

ScotT ('00): D. H. Scott, Studies in Fossil Botany, Ist ed., p. 277.

('08): Studies in Fossil Botany, 2nd ed., p. 306.

Stenzel ('89): G. Stenzel, Die Gattung Tubicaulis, Cotta. Mitth. aus dem K. Min., Geol. u. Praehist. Mus. in Dresden, Heft 8.

('96) : Nachträgliche Bemerkungen zur 'Gattung Tubicaulis, Cotta'. Bot. Zeit., Jahrgang liv, p. 27 .

Williamson ('74): W: C. Williamson, On the Organization of the Fossil Plants of the Coal-

Measures. Part VI. Ferns. Phil. Trans. Royal Soc., 1874, p. 698, Fig. 5 I.

('89) : On the Organization of the Fossil Plants of the Coal-Measures. Part XV

Phil. Trans. Royal Soc., I889, B., p. I55, Figs. I-5 A. (Read in I888.)

\title{
EXPLANATION OF PLATES I-V.
}

\author{
Illustrating Dr. Scott's paper on Zygopteris (Ankyropteris) Grayi.
}

The Photographs in Plates I and II often need to be examined with a lens.

\section{PLATE I.}

(Photographs by Mr. W. Tams.)

Shore specimen.

Phots. I-6. Selections from the transverse series of sections, from below upwards. Phots. I, 2, 3,5 , and 6 show the stele and surrounding tissues. Phot. 4, on a smaller scale, shows the whole stem.

Phot. I. (Reversed, as compared with Phots. 2-6.) The arms of the stele are numbered I-5, following the phyllotaxis in kathodic order. The leaf-trace, l.t. (incomplete), and axillary stele, a.s., are shown in the outer cortex. $\times 8$. Scott Coll., 2511 .

Phot. 2. The arm 5 is spreading out laterally and its internal ray becoming interrupted. $\times 8$. Scott Coll., 25 I 2.

Phot. 3. The end of arm 5 is about to separate as a leaf-trace. $\times 8$. Scott Coll., $25^{1} 4$.

Phot. 4. Complete section. The leaf-trace 5 has now separated (see Phot. 8). Numerous aphlebia-strands are seen in the cortex. $\times 4$. Scott Coll., 2516.

Phot. 5. The leaf-trace 5 has now entered the cortex. $\times 8$. Scott Coll., 2518.

Phot. 6. The leaf-trace 5 has passed out further into the cortex and is assuming a stouter form. The arm 4 is preparing to detach its leaf-trace. $\times 8$. Scott Coll., 2520.

Phot. 7. Middle part of stele, showing irregular ring of internal xylem, $x . i$, with the five internal protoxylem rays. $x$ about 30 . Scott Coll., 2516.

Phot. 8. Leaf-trace 5 (see Phot. 4). x.e., peripheral loops formed by the small-celled external 
xylem ; x.i., median island of internal xylem, destined for the axillary stele. $\mathrm{x}$ about 30. Scott Coll., 2516.

Phot. 9. Foliar bundle, in oblique section, from the base of a petiole in connexion with the stem. x.e., peripheral loop; s.v.b., base of a secondary vascular bundle belonging to a pinna. $\times$ 8. Scott Coll., 2530 .

\section{PLATE II.}

(Photographs I0-I 3 by Mr. L. A. Boodle, F.L.S.; I4-I6 by Mr. W. Tams.) Photographs IO-I4 from Williamson's later specimen.

Phot. 10. Axillary stele, from the transverse section figured as a whole in Scott, '08, Fig. II 5 . $x . i$, band of internal xylem, tangential to the parent stem; ph., phloem; i.c., inner cortex of the axillary shoot. $\times 34$. Williamson Coll., I919 A.

Phots. II-I3. General transverse sections.

Phot. I I. Leaf-base prominent. st., stele of stem; l.t., leaf-trace in the act of separating from the axillary stele; aph., aphlebiae, two in connexion with the leaf-base, and the third in connexion with the stem. The strands of other aphlebiae are seen in the cortex. $x$ about 4 . Williamson Coll., I9I9 D.

Phot. I 2. Here the foliar bundle, l.t., and the axillary stele, a.s., have already separated. For details see Pl. V, Fig. 13. $\times$ about 4. Williamson Coll., I919 в.

Phot. I3. (Reversed, as compared with Phots. II and I2.) Pet., petiole, in oblique section, with the axilllary shoot, not yet quite free, between petiole and stem; a.s., axillary stele; l.t.', another leaf-trace, diverging from the former by $\frac{2}{5}$, just leaving the stele. $x$ about 4 . Williamson Coll., I9I9 c.

Phot. 14. Undivided leaf-trace in the outer cortex. x.e., small tracheides of a peripheral loop. The position of this trace is shown in the diagram, Pl. V, Fig. I5, l.t. $\times 35$. Scott Coll., I84.

Phots. I 5 and 16 from Williamson's type-specimens.

Phot. I5. Transverse section of a stem, showing the stele and surrounding tissues (imperfectly preserved). l.t., crescentic leaf-trace, as in the Shore specimen; aph.b., aphlebia-bundle (several shown); r., root passing out through cortex. $\times 7$. Williamson Coll., I824.

Phot. 16. Transverse section of the vascular bundle of the petiole and adjacent tissues. x.e., small-celled external xylem of the peripheral loops. $\times 26$. Williamson Coll., I824.

\section{PLATE III.}

Figs. I, 3, and 5 by Miss G. C. Harrison. Figs. 2, 4, and 6 by Mr. G. T. Gwilliam.

Shore specimen.

Fig. I. Undivided leaf-trace, after entering the cortex (level of section between that of Phots. 5 and 6 ). $x$., large-celled xylem; x.e., small-celled external xylem of the peripheral loops; $p x$., probable positions of protoxylem; $x . i$., island of internal xylem, destined for the axillary stele ; ph., remains of phloem; i.c., band of inner cortex between leaf-trace and stele. $x$ about 40. Scott Coll., 25 I9.

Fig. 2. Leaf-trace further out in cortex. Rather more than half is shown (level two sections above Phot. 6). Note the increased width of the middle part of the trace, in preparation for the detachment of the axillary stele. Lettering explained under Fig. I. $\times 50$. Scott Coll., 2522.

Fig. 3. Longitudinal section of the stele of the stem passing tangentially through the 'mixed pith', and showing the internal xylem, x.i., at several places. p.p., parenchymatous cells; $x . x$., inner edges of the outer, large-celled xylem-zone. $\times$ roo. Scott Coll., $25^{2} 5$.

Fig. 4. Transverse section of arm 2 of stele (level immediately above Phot. 6). x.i., internal protoxylem ray, the forks nearly reaching the surface of the xylem; aph., aphlebia-strand, given off from the arm of the stele. $\times 65$. Scott Coll., $25^{2} \mathrm{I}$.

Fig. 5. Part of leaf-trace, just detached from arm 5 of the stele (level between Phot. 3 and Phot. 4), showing one of the peripheral loops and an aphlebia-strand just given off and still in connexion. $x . e$. , external xylem of peripheral loop; ph., remains of phloem; aph., the aphlebiastrand. $\times$ 120. Scott Coll., 25 I5. 
Fig. 6. Aphlebia-strand, v.b., in the outer cortex. The strand is much extended tangentially. $\times$ 40. Scott Coll., 2516 .

\section{PLATE IV.}

Fig. 9 by Miss G. C. Harrison ; the others by Mr. G. T. Gwilliam. Figs. 7-Io, Shore specimen.

Fig. 7. Aphlebia detached from cortex of stem, c. v.b., one of the vascular bundles of the aphlebia; the other is only indicated by a gap in the tissue; $k$., multicellular hairs of the stem. $\times$ 30. Scott Coll., 2516 .

Fig. 8. Somewhat diagrammatic longitudinal section of stem. The cross-hatched area is the onter cortex, st., stele, cut rather obliquely so that the 'mixed pith' is seen below, and two of the internal rays, passing out from it, above. aph., aphlebia-strand, passing out through the cortex. $\times 5$. Scott Coll., 2525 .

Fig. 9. Transverse section of an axillary stele (the same as shown in Phot. $\mathrm{I}$, but two sections higher up). $x . i$, internal xylem; $p$., parenchyma of the 'mixed pith'; $x$., large-celled xylem-zone ; c., part of cortex ; $\rightarrow S$., direction of main stele of stem. $\times 44$. Scott Coll., 2513 .

Fig. Io. Longitudinal section of another axillary stele, passing through the 'mixed pith'. $x . i$, internal xylem; $p x$., protoxylem, consisting of spiral tracheides; the parenchyma of the 'mixed pith' is shown above; $x$, large-celled xylem-zone. $\times$ yo. Scott Coll., 2527.

Figs. I I, I 2. Williamson's later specimen.

Fig. II. Undivided leaf-trace in the outer cortex, the same as shown in Pl. II, Phot. I4, and in the diagram Pl. V, Fig. 15 , l.t. x.e., small-celled external xylem of a peripheral loop. $x$ about 5 . Scott Coll., 184 .

Fig. I 2. Undivided leaf-trace on the border of the inner and outer cortex. From section figured in Scott, '08, Fig. II 5. A zone of inner cortex surrounds the trace. $x$.i., internal xylem; $x$., outer xylem-zone; ph., phloem with large sieve-tubes. $\times 28$. Williamson Coll., I919A.

\section{PLATE V.}

Figures by Mr. G. T. Gwilliam, from Williamson's later specimen.

Fig. I3. Foliar bundle, L.T., and axillary stele, A.S., just separated, with inner and outer cortex between them; whole section shown in Pl. II, Phot. I2. $x$., $x$., large-celled xylem of bundle and axillary stele; $p h ., p h .$, phloem of bundle and stele; $x . i$., internal xylem of stele. $\times 28$. Williamson Coll., I919 B.

Fig. I4. Arm of stele, st., in transverse section, giving off laterally the stele of a root, $r t$.; c., inner cortex. $x$ about 40. Manchester Coll., R. 443 .

Fig. 15. Diagram of transverse section, showing relative positions of the stele, st.; an undivided leaf-trace, l.t. (shown in Pl. II, Phot. I4, and Plate IV, Fig. II); a foliar bundle, f.b., and its axillary stele, a.s. The gap in the cortex was filled by a Stigmarian rootlet. $\times 6$. Scott Coll., 184 . 

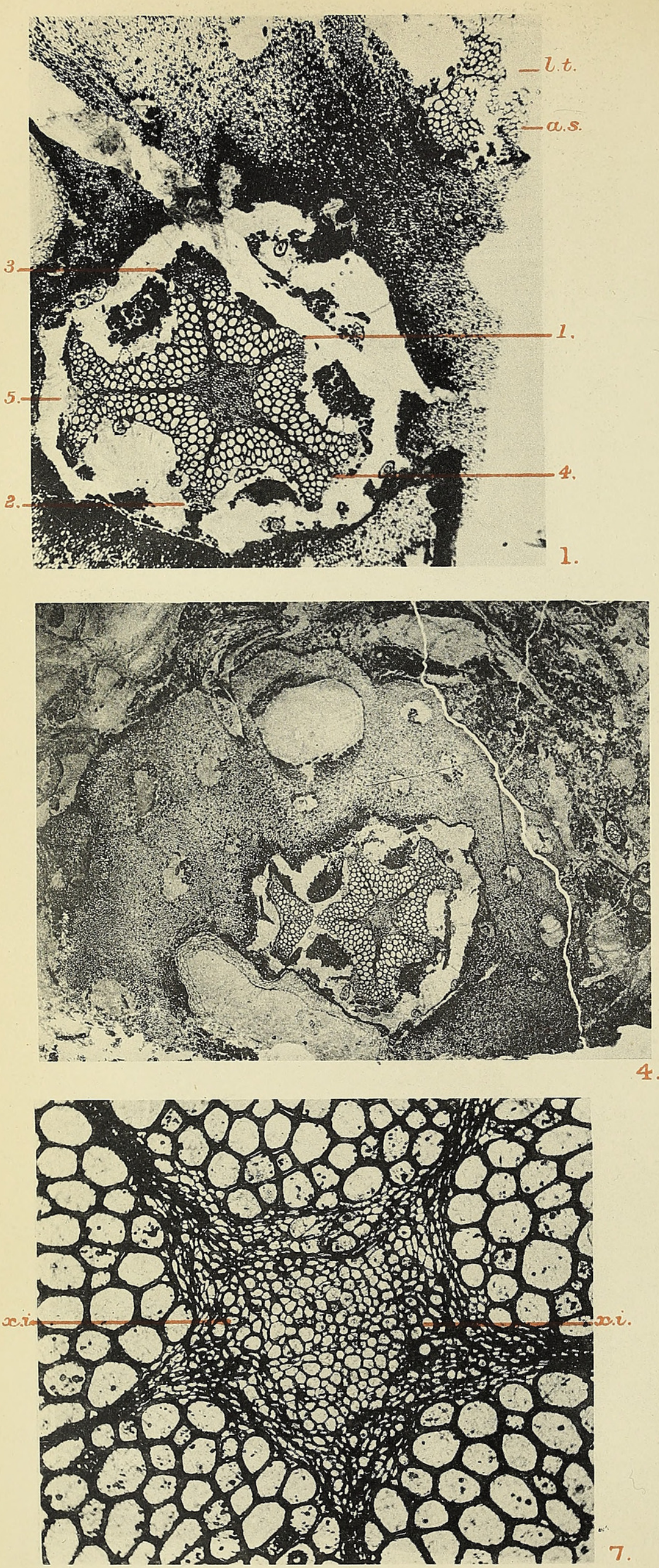
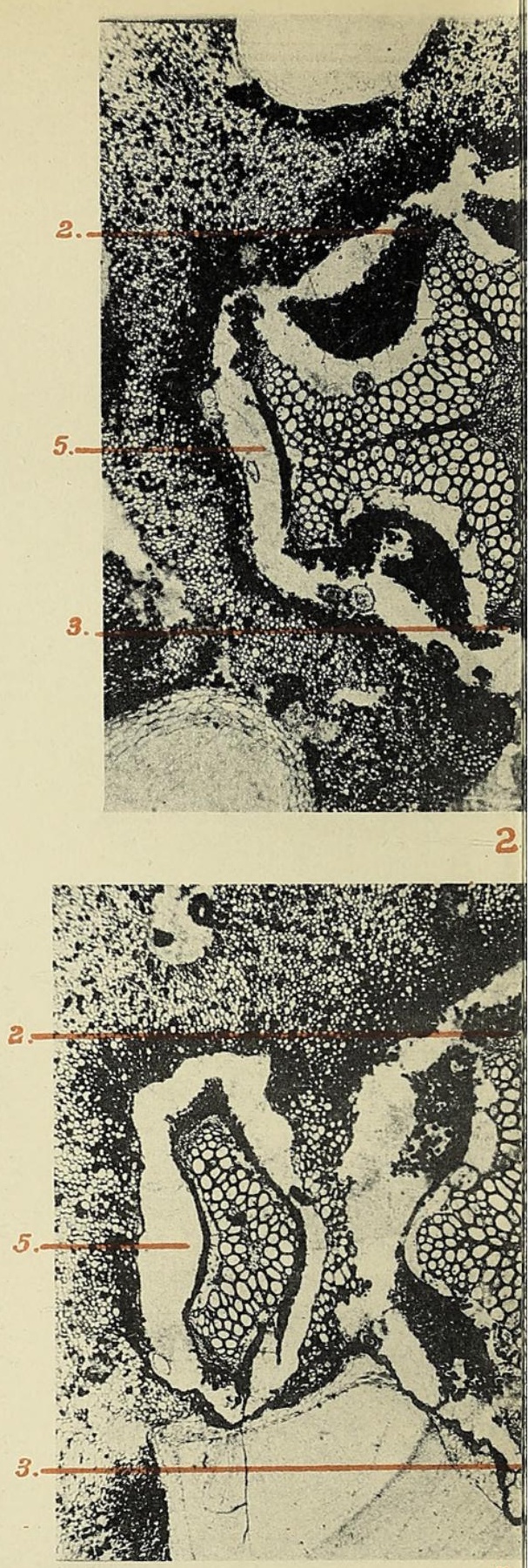

4.

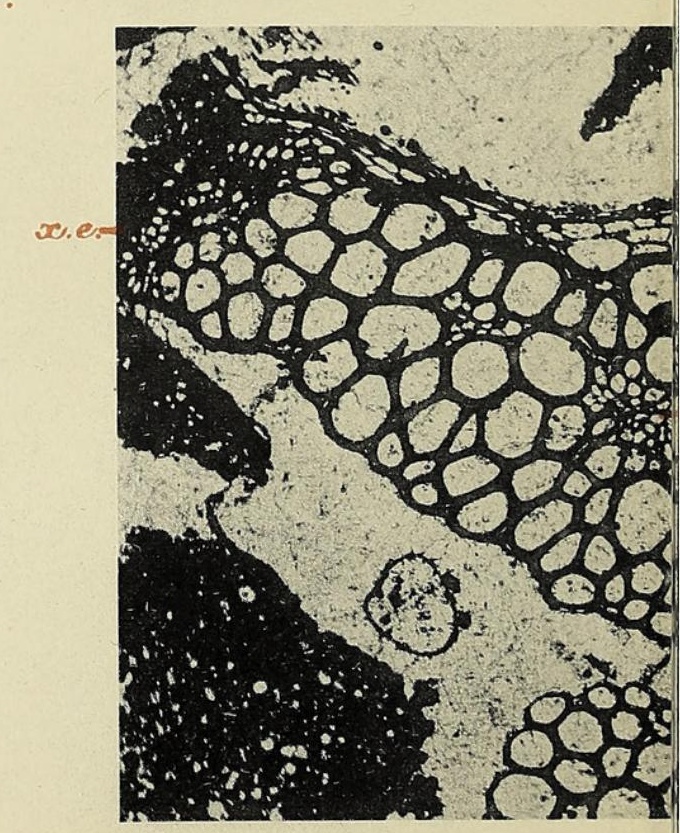



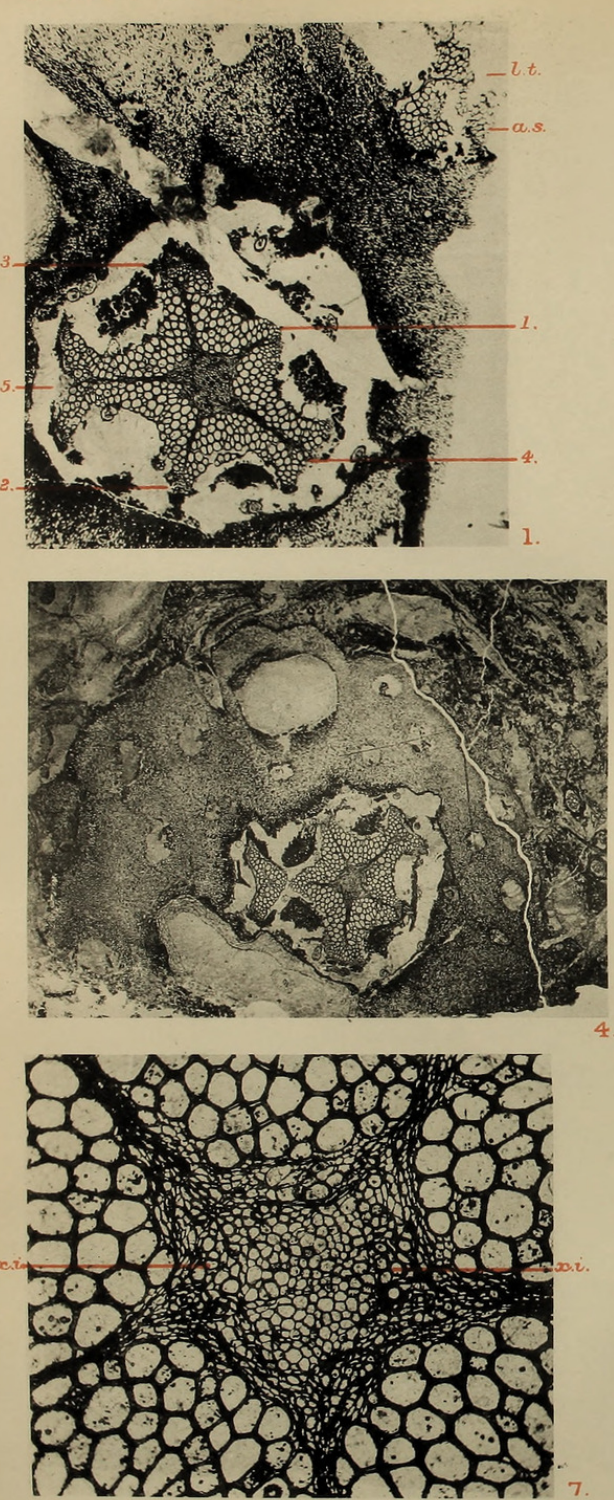
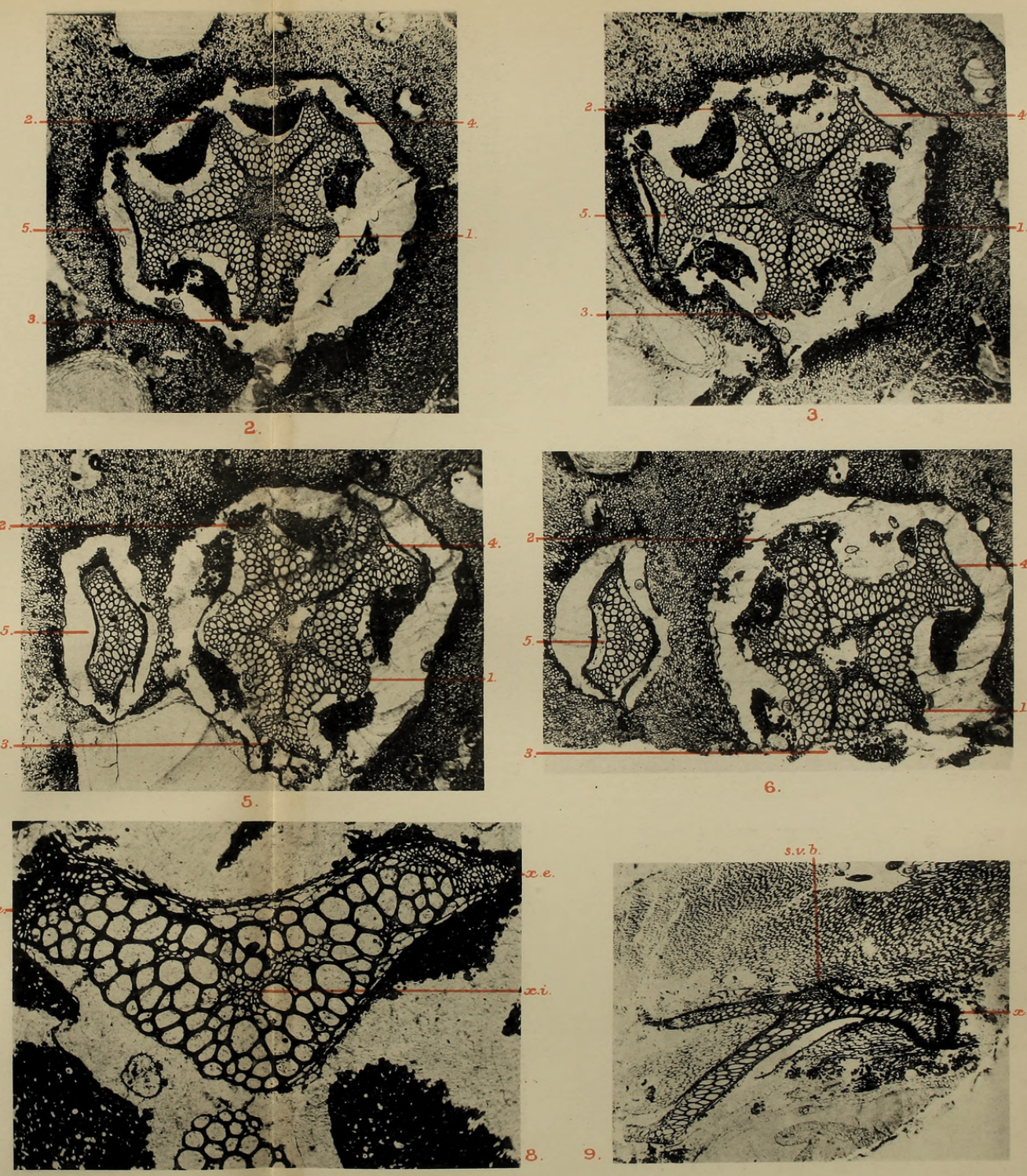

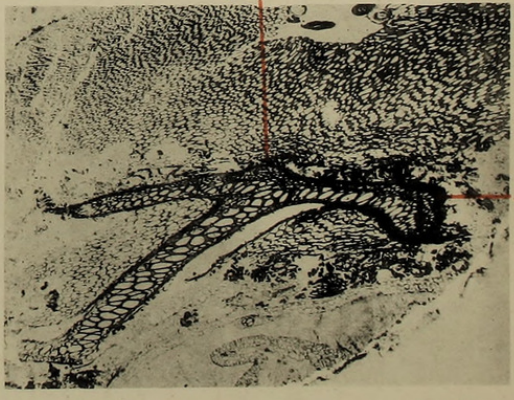




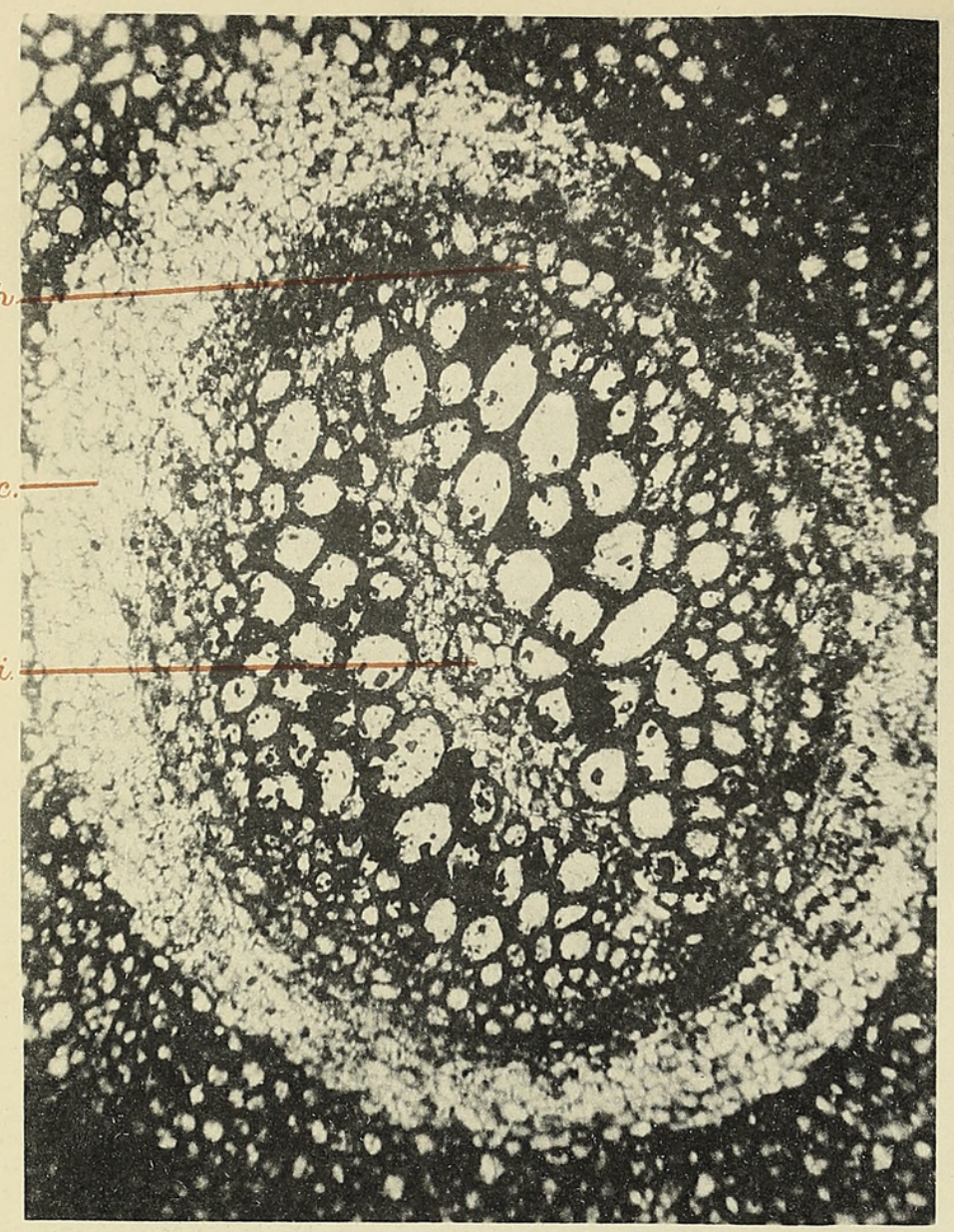

10

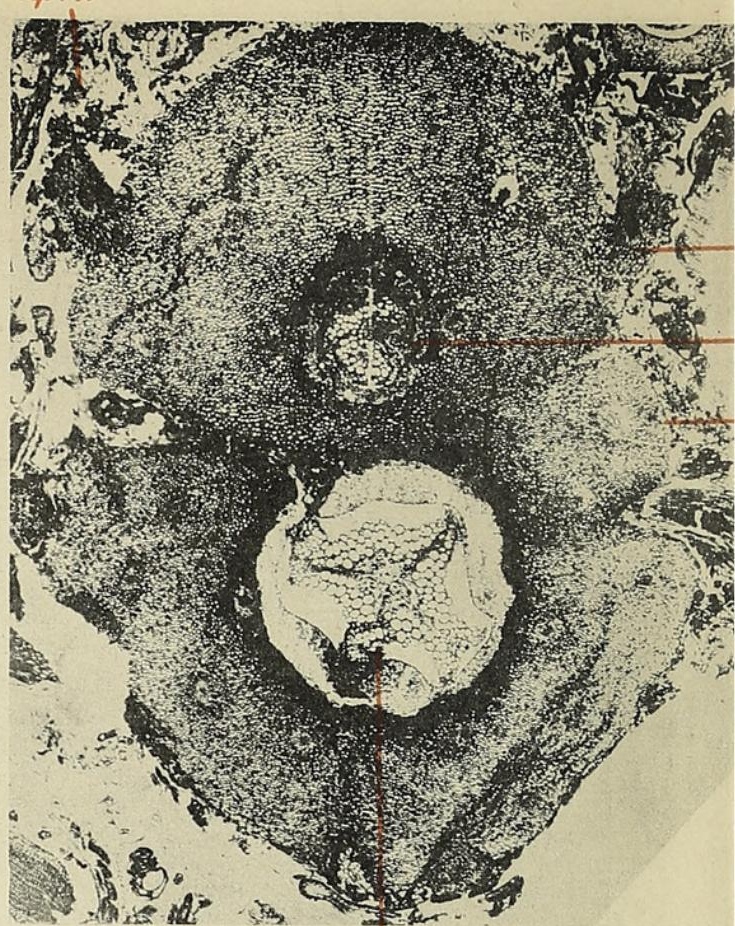

11

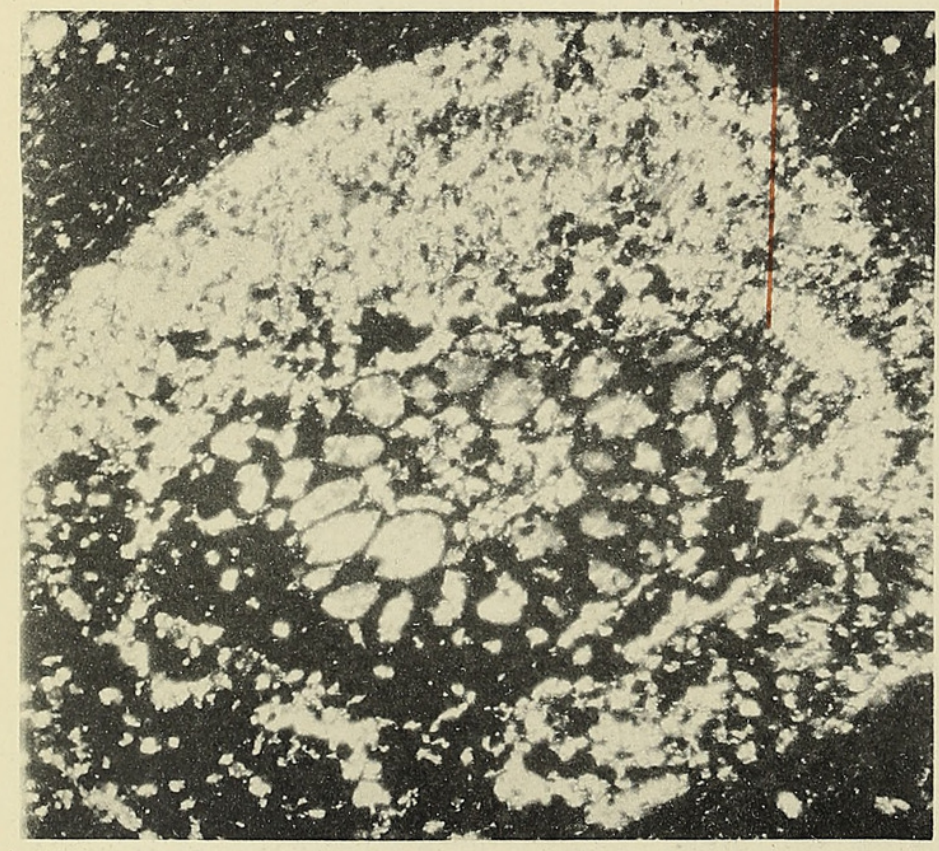

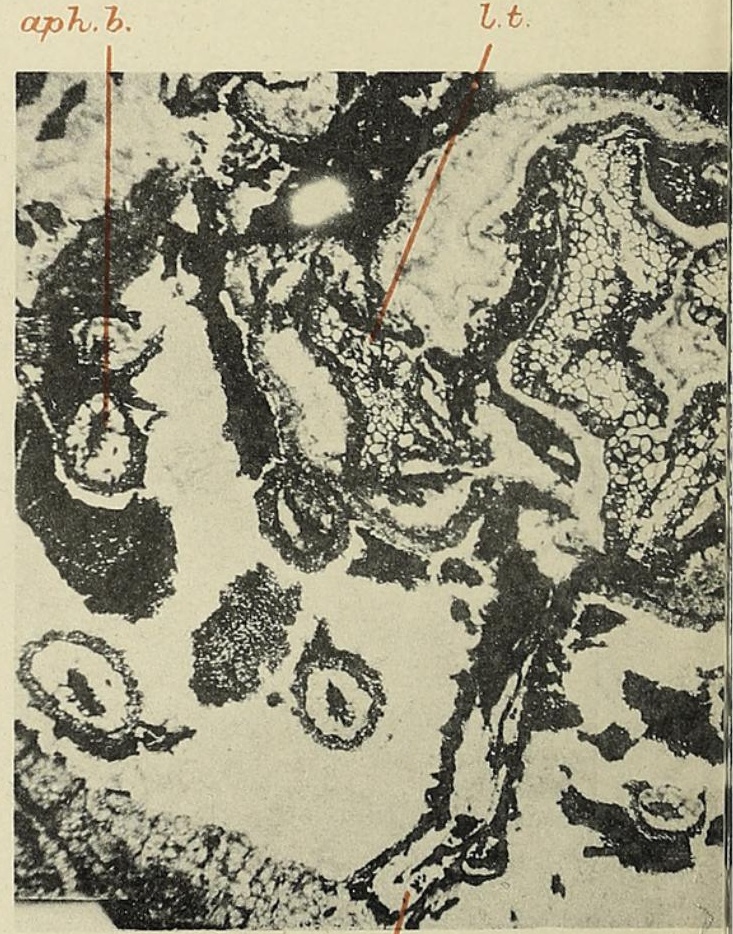




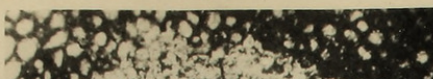

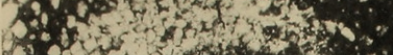
(2)

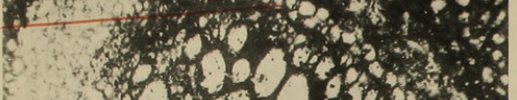

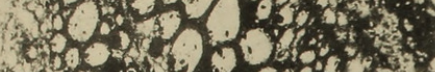
Mo 1045 4 . $018 \%$ istoroto

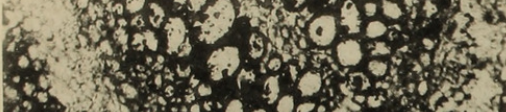
a.t. 380 (3) $-20 \%$

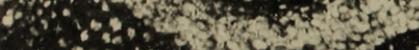

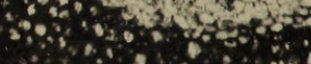

(1)

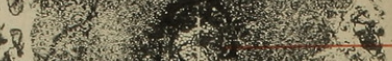

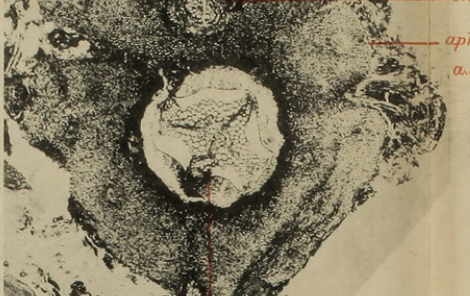

6is: $=10$
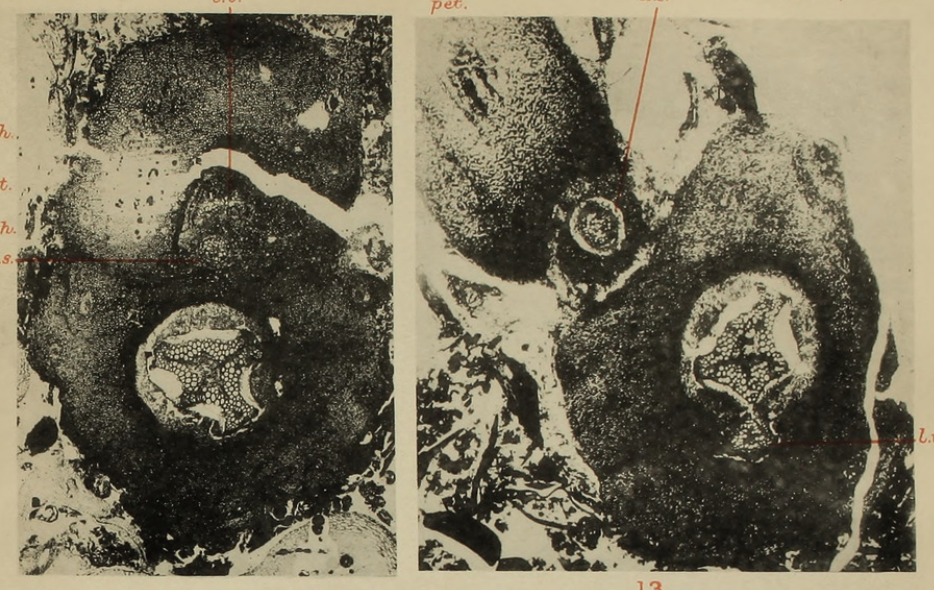
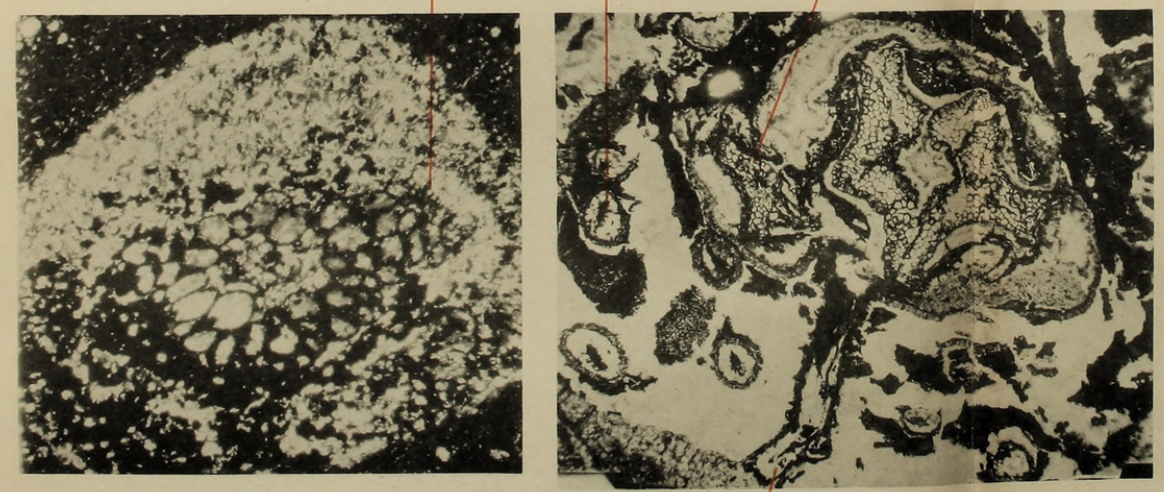

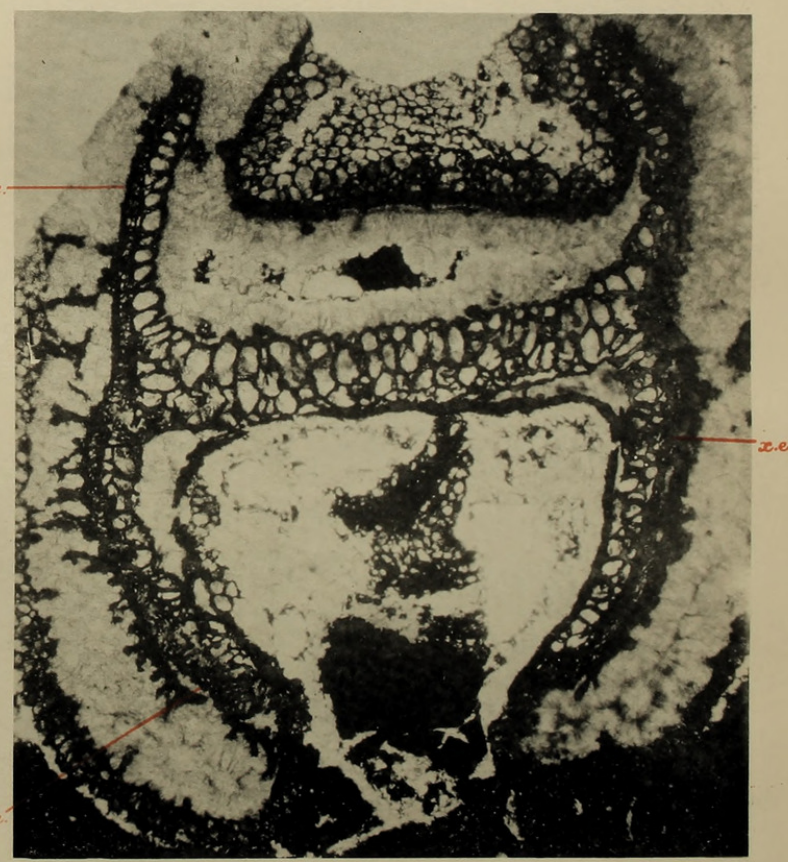


Annals of Botary. 


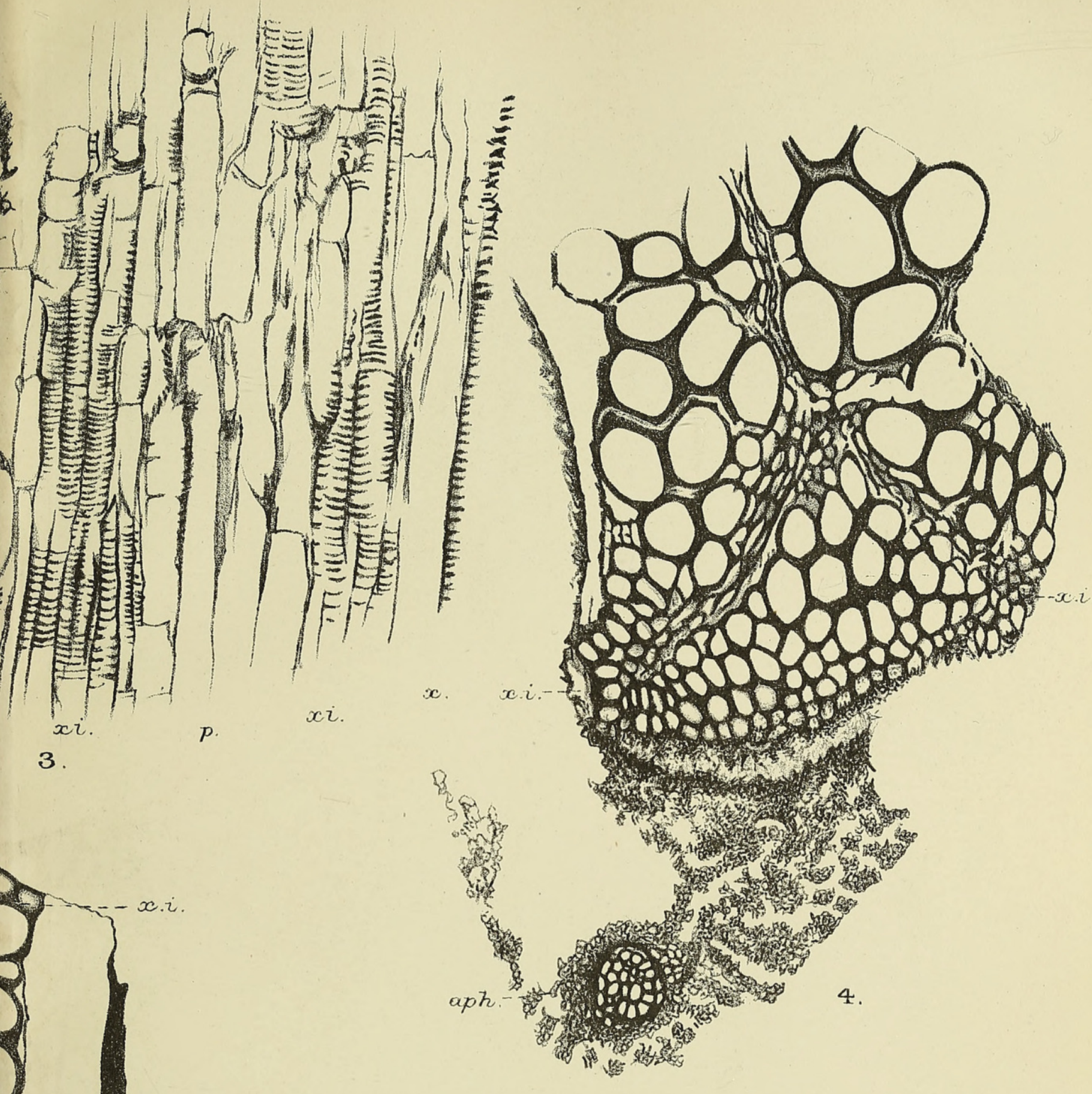

v. $b$.

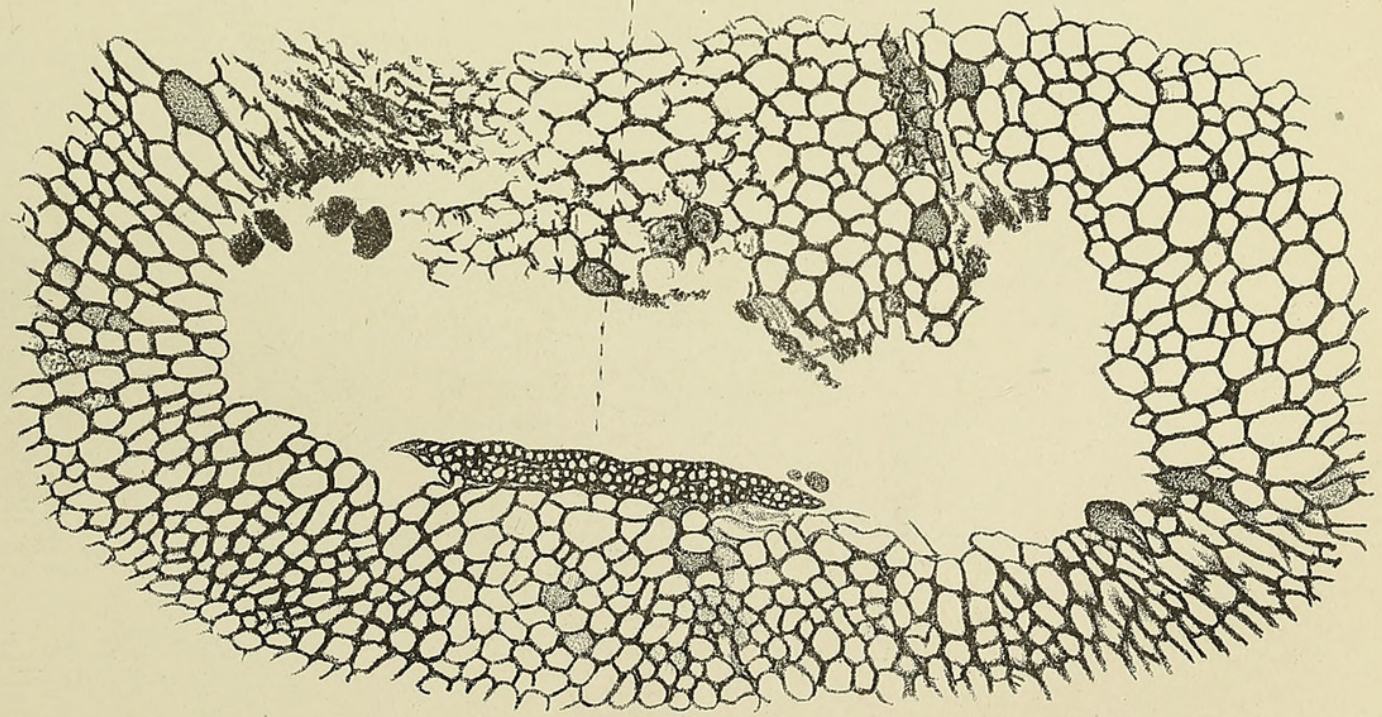

6. 


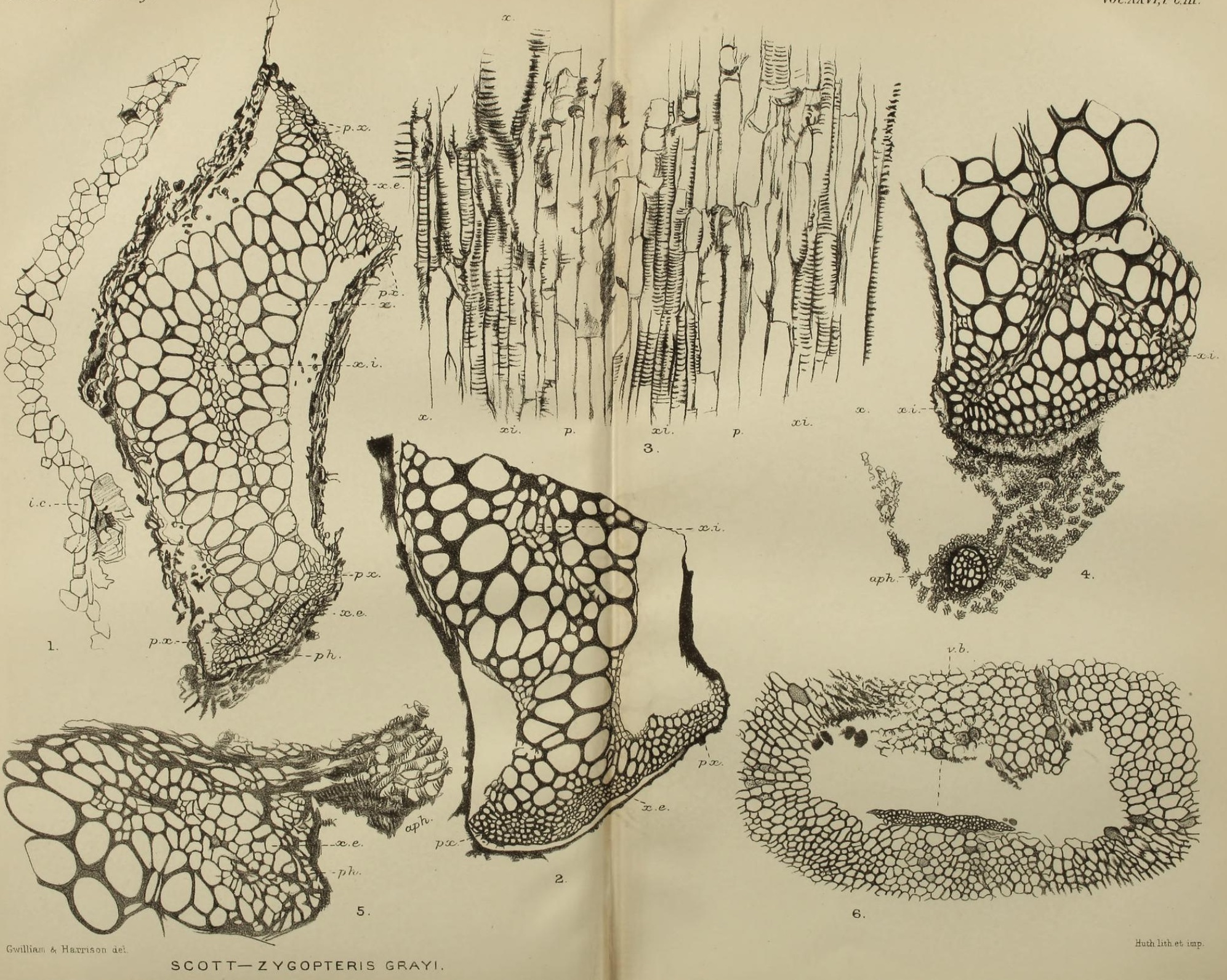


Annals of Botany.

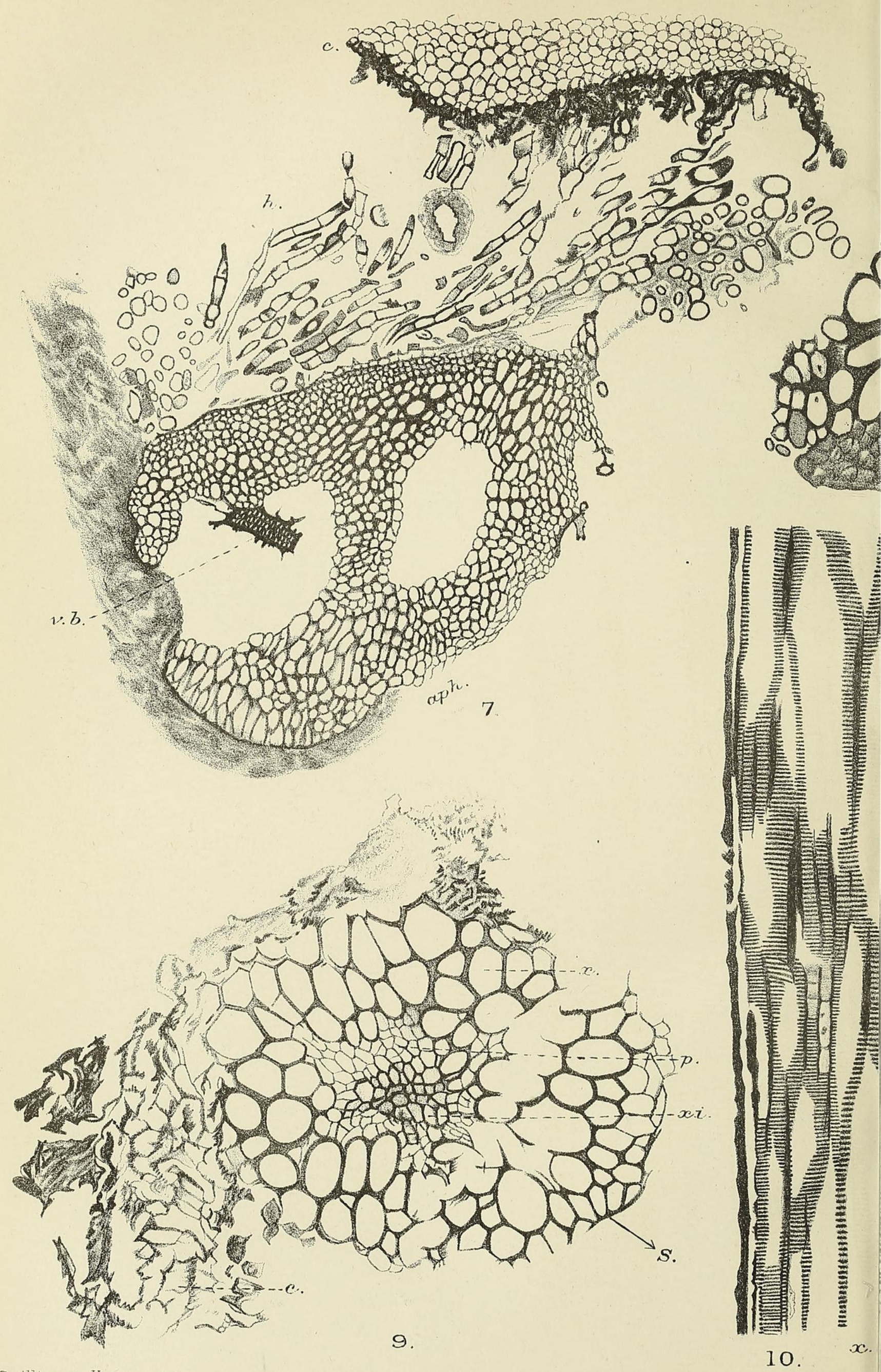



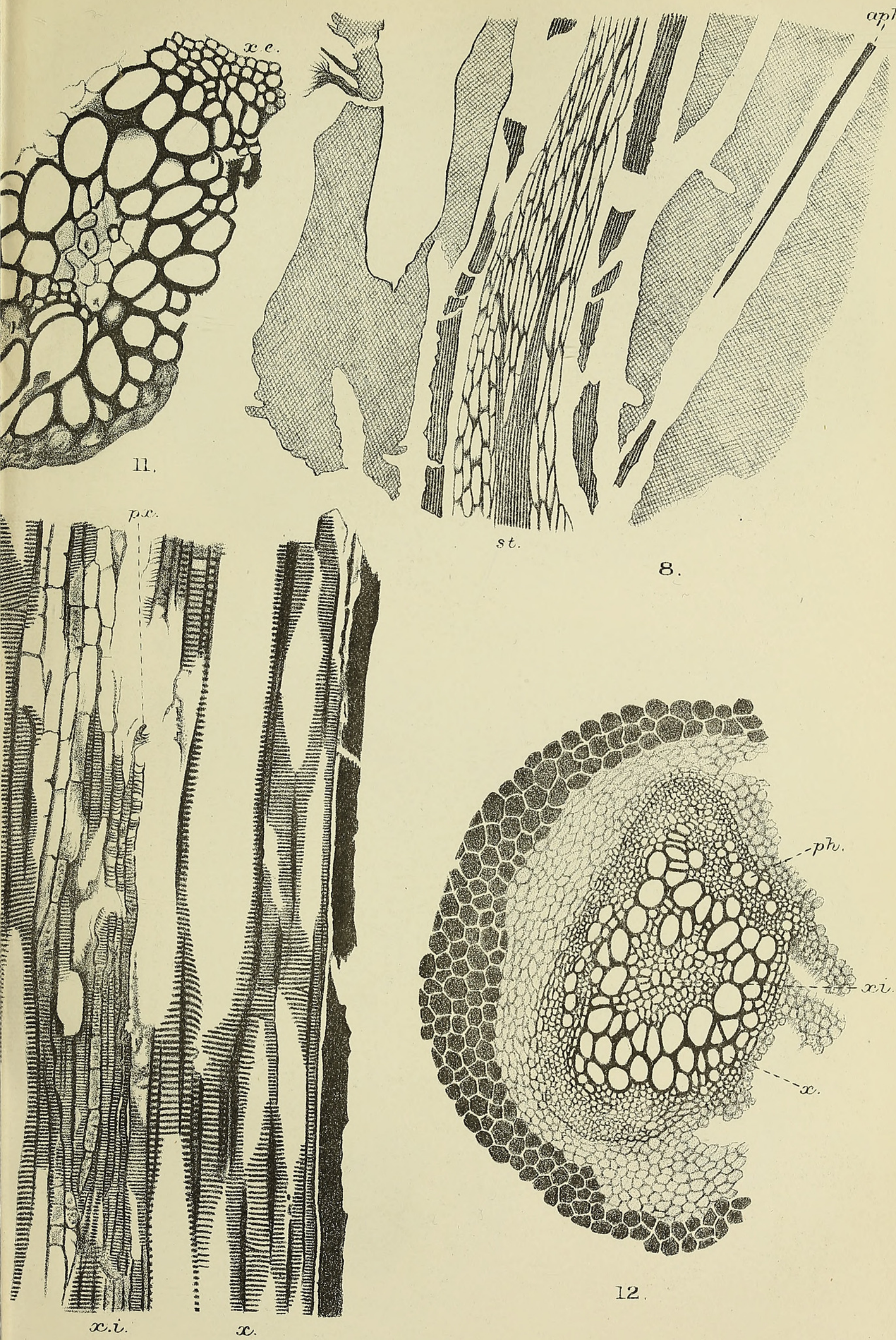

8.

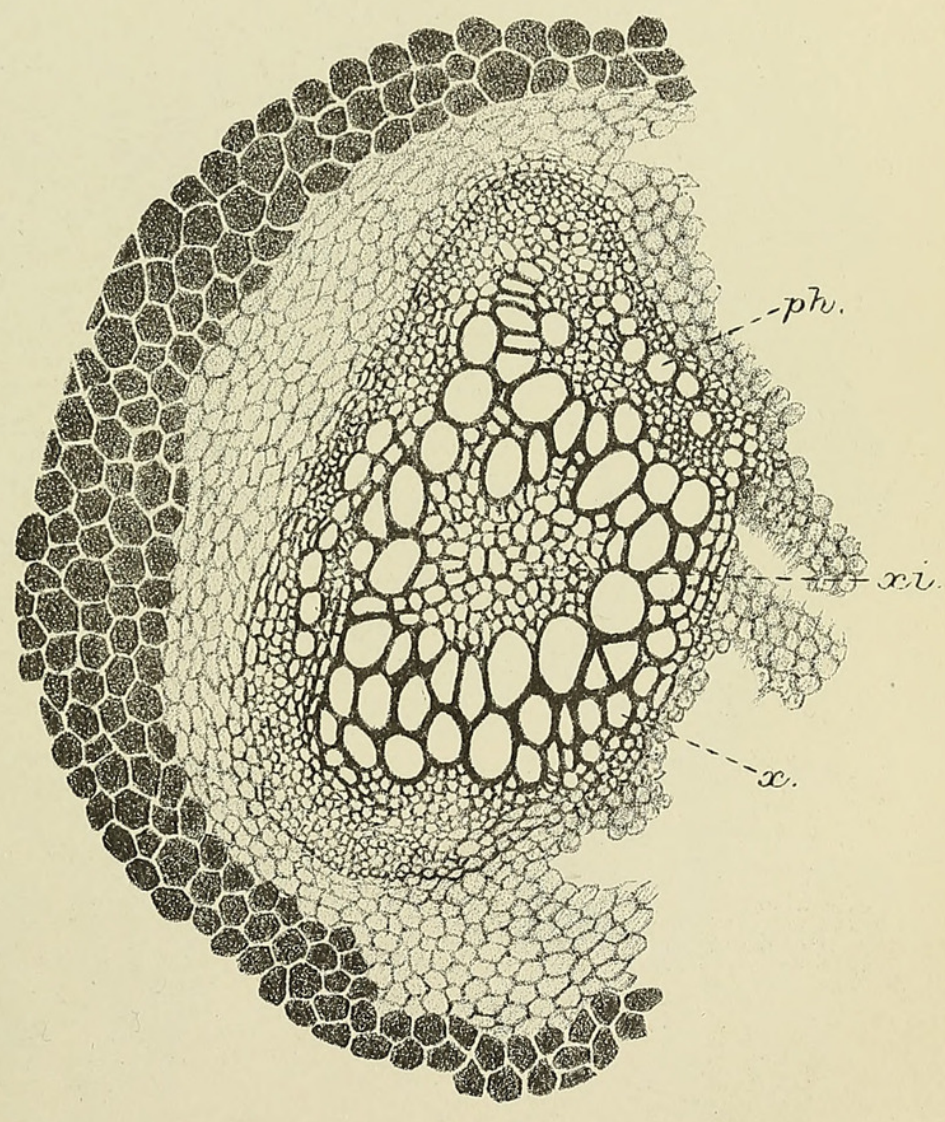

12 


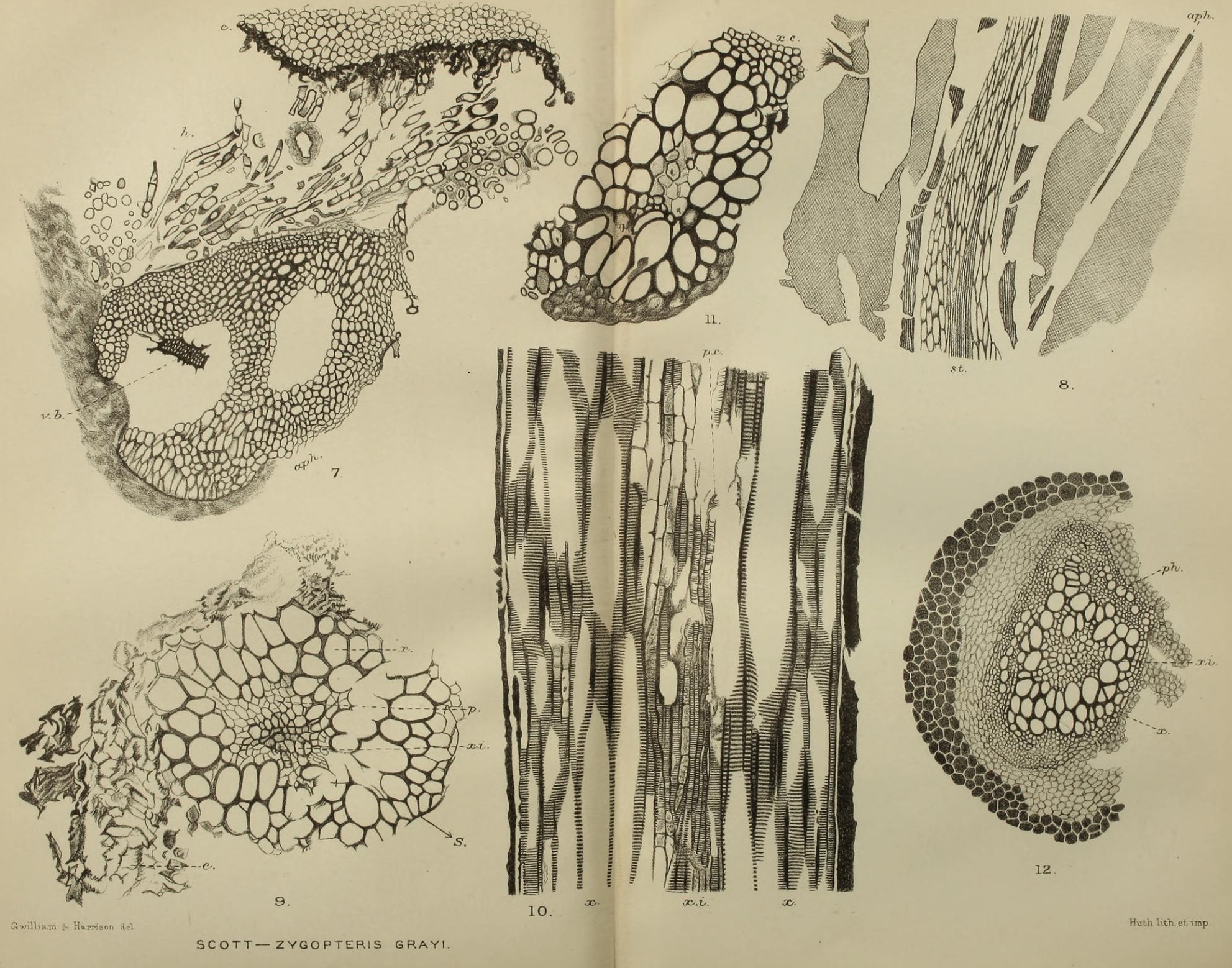




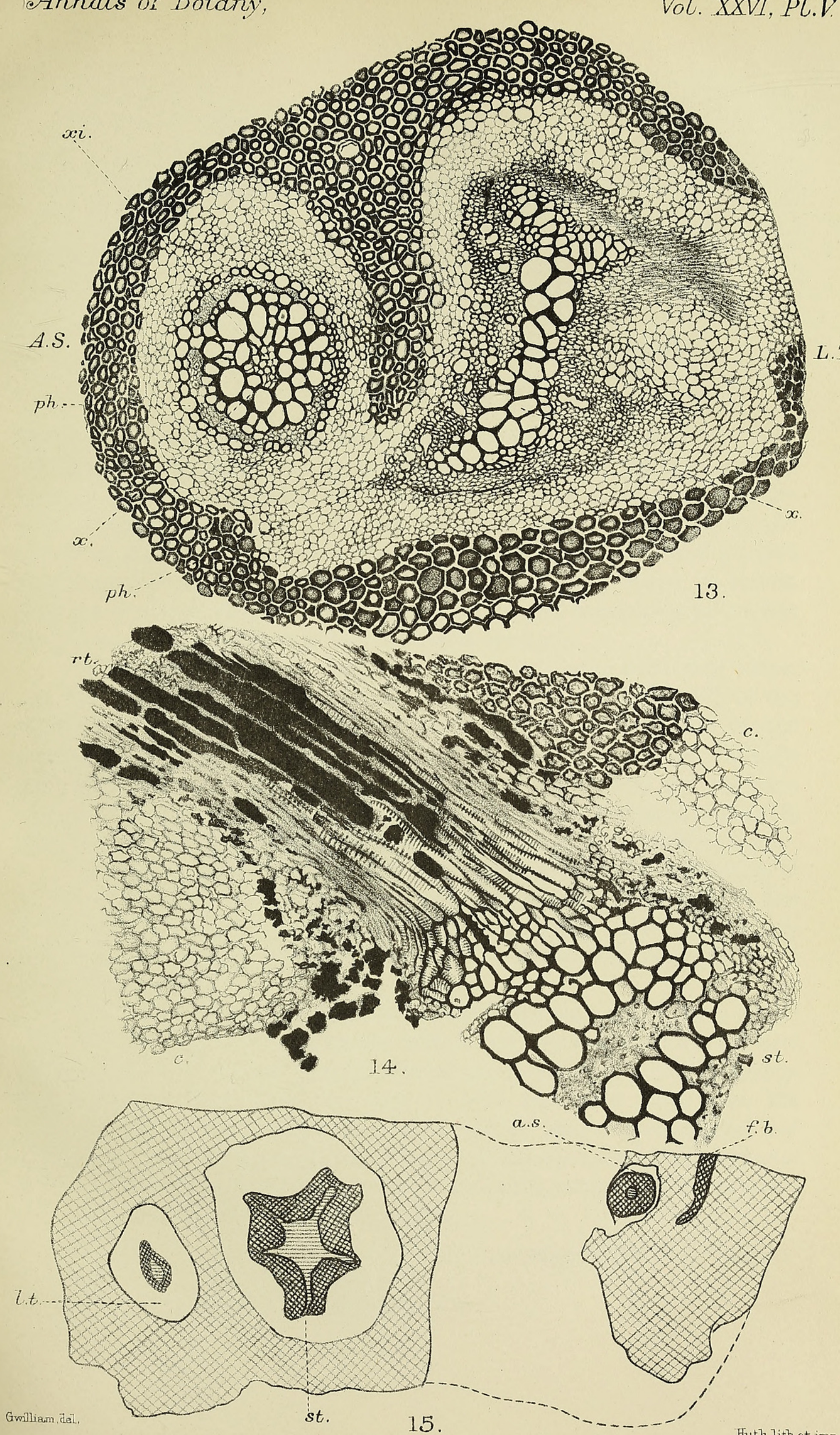




\section{$2 \mathrm{BHL}$ Biodiversity Heritage Library}

Scott, Dukinfield Henry. 1912. "On a palaeozoic fern, the Zygopteris grayi of Williamson." Annals of botany 26, 39-69.

https://doi.org/10.1093/oxfordjournals.aob.a089389.

View This Item Online: https://www.biodiversitylibrary.org/item/236773

DOI: https://doi.org/10.1093/oxfordjournals.aob.a089389

Permalink: https://www.biodiversitylibrary.org/partpdf/319892

\section{Holding Institution}

Smithsonian Libraries

\section{Sponsored by}

Biodiversity Heritage Library

\section{Copyright \& Reuse}

Copyright Status: Not in copyright. The BHL knows of no copyright restrictions on this item.

This document was created from content at the Biodiversity Heritage Library, the world's largest open access digital library for biodiversity literature and archives. Visit BHL at https://www.biodiversitylibrary.org. 